\title{
Raw Bowl Tea (Tuocha) Polyphenol Prevention of Nonalcoholic Fatty Liver Disease by Regulating Intestinal Function in Mice
}

\author{
Bihui Liu ${ }^{1,2,3,4}$, Jing Zhang ${ }^{5}$, Peng Sun ${ }^{1,2,3,4}$, Ruokun Yi ${ }^{1,2,3}$, Xiaoyan Han ${ }^{1,4}$ and \\ Xin Zhao $1,2,3, * \mathbb{D}$ \\ 1 Chongqing Collaborative Innovation Center for Functional Food, Chongqing University of Education, \\ Chongqing 400067, China \\ 2 Chongqing Engineering Research Center of Functional Food, Chongqing University of Education, \\ Chongqing 400067, China \\ 3 Chongqing Engineering Laboratory for Research and Development of Functional Food, Chongqing \\ University of Education, Chongqing 400067, China \\ 4 College of Biological and Chemical Engineering, Chongqing University of Education, \\ Chongqing 400067, China \\ 5 Environment and Quality Inspection College, Chongqing Chemical Industry Vocational College, \\ Chongqing 401228, China \\ * Correspondence: zhaoxin@cque.edu.cn; Tel.: +86-23-6265-3650; Fax: +86-23-6265-3650
}

Received: 27 August 2019; Accepted: 30 August 2019; Published: 1 September 2019

Abstract: A high-fat diet-induced C57BL/6N mouse model of non-alcoholic fatty liver disease (NAFLD) was established. The effect and mechanism of Raw Bowl Tea polyphenols (RBTP) on preventing NAFLD via regulating intestinal function were observed. The serum, liver, epididymis, small intestine tissues, and feces of mice were examined by biochemical and molecular biological methods, and the composition of RBTP was analyzed by HPLC assay. The results showed that RBTP could effectively reduce the body weight, liver weight, and liver index of NAFLD mice. The serum effects of RBTP were: (1) decreases in alanine aminotransferase (ALT), aspartate aminotransferase (AST), alkaline phosphatase (AKP), total cholesterol (TC), triglyceride (TG), low density lipoprotein cholesterol (LDL-C), D-lactate (D-LA), diamine oxidase (DAO), lipopolysaccharide (LPS), and an increase of high density lipoprotein cholesterol (HDL-C) levels; (2) a decrease of inflammatory cytokines such as interleukin 1 beta (IL-1 $\beta$ ), interleukin 4 (IL-4), interleukin 6 (IL-6), interleukin 10 (IL-10), tumor necrosis factor alpha (TNF- $\alpha$ ), and interferon gamma (INF- $\gamma$ ); (3) a decrease the reactive oxygen species (ROS) level in liver tissue; and (4) alleviation of pathological injuries of liver, epididymis, and small intestinal tissues caused by NAFLD and protection of body tissues. qPCR and Western blot results showed that RBTP could up-regulate the mRNA and protein expressions of LPL, PPAR- $\alpha$, CYP7A1, and CPT1, and down-regulate PPAR- $\gamma$ and C/EBP- $\alpha$ in the liver of NAFLD mice. In addition, RBTP up-regulated the expression of occludin and ZO-1, and down-regulated the expression of CD36 and TNF- $\alpha$ in the small intestines of NAFLD mice. Studies on mice feces showed that RBTP reduced the level of Firmicutes and increased the minimum levels of Bacteroides and Akkermansia, as well as reduced the proportion of Firmicutes/Bacteroides in the feces of NAFLD mice, which play a role in regulating intestinal microecology. Component analysis showed that RBTP contained seven polyphenolic compounds: Gallic acid, (-)-epigallocatechin, catechin, L-epicatechin, (-)-epigallocatechin gallate, (-)-gallocatechin gallate, and (-)-epicatechin gallate (ECG), and high levels of caffeine, (-)-epigallocatechin (EGC), and ECG. RBTP improved the intestinal environment of NAFLD mice with the contained active ingredients, thus playing a role in preventing NAFLD. The effect was positively correlated with the dose of $100 \mathrm{mg} / \mathrm{kg}$, which was even better than that of the clinical drug bezafibrate. 
Keywords: raw Bowl tea; polyphenols; nonalcoholic fatty liver disease; mice; intestinal function

\section{Introduction}

Nonalcoholic fatty liver disease (NAFLD) is a multifactorial disease, associated with a complex living environment, heredity, and dietary habits. High calorie diets and prolonged inactivity contribute to weight gain by promoting the development of NAFLD [1]. The most common cause of NAFLD is systemic energy imbalance, with calorie intakes exceeding calorie consumption. Excess visceral adipose tissue contributes to ectopic fat in liver, skeletal muscle, and pancreas in the form of non-esterified fatty acids (NEFA) [2]. Accumulation of triglycerides in liver and blood further aggravate NAFLD. Both exercise and improved diet can reduce the risk of NAFLD [3].

Bowl Tea is a compacted tea with a conical and steamed corn-bread shape, which is produced from steamed high-quality sun-dried green teas. Its main origin is the Yunnan Province of China. Yunnan Bowl Tea is also called Xiaguan Bowl Tea since it was developed in Xiaguan, Yunnan. Similar to Pu'er Tea, Xiaguan Bowl Tea is a dark tea that can be divided into raw and ripe Bowl Teas. Raw Bowl Tea is compacted tea made directly from sun-dried green tea fermented by artificial heap fermentation [4]. Clinical studies have shown that Bowl Tea has a significant weight loss effect in people aged 40-50 years. More than $70 \%$ of the cases show that Bowl Tea significantly reduced the levels of triglyceride in the human body [5]. In some experiments, participants drank three cups of Bowl Tea per day for a month, with a decrease in the cholesterol levels in half of the subjects [6]. The lipid-lowering effect of Yunnan Bowl Tea is similar to that of the lipid-lowering drug, clofibrate, with a lipid-lowering rate of 64\% [7]. However, there is still no definitive evidence to prove the specific mechanism of Bowl Tea on weight loss and lipid metabolism, and the specific efficacy components are unclear.

During the development of NAFLD, excessive free fatty acid deposition is the "first-hit". Accumulated free fatty acid that injures the liver is the "second-hit" through reactive oxides, promoting the conversion of simple fatty liver disease to nonalcoholic steatohepatitis and cirrhosis [8]. Owing to the oxidation of a large number of free fatty acids and the activation of bypass pathways of fatty acid metabolism, excessive reactive oxygen species (ROS) are produced, resulting in hepatocyte injury and the activation of hepatic stellate cells (HSC). At the same time, the ability of steatotic hepatocytes to remove intestinal endotoxins is lowered, and fat tissue is stimulated by endotoxins to produce inflammatory factors that further enhance insulin resistance and HSC activation and promote the occurrence of hepatic fibrosis [9].

The intestinal tract plays an important role in the development of NAFLD. The absorption of long-chain fatty acids (LCFA) in the main components after fat digestion is closely related to the structural integrity and function of the small intestine. The weakening of the intestinal mucosal barrier function allows more bacterial endotoxins to diffuse into the blood circulation, causing liver cell damage through a series of inflammatory reactions [10]. The occurrence of NAFLD is also closely related to the changes in intestinal flora. Intestinal harmful bacteria, typically flagellated Gram-negative bacteria, increase in NAFLD patients, which will then be accompanied by the changes in the intestinal permeability and a systemic low-grade chronic inflammatory response [11]. In addition, studies have shown that the disorder of the intestinal flora will lead to increased absorption of free fatty acids and reduced heat production, which will eventually cause NAFLD by increasing the amount of stored fat [12]. Studies have shown that tea polyphenols have a good antioxidant effect and an excellent regulatory efficacy on the NAFLD-induced oxidative level in rats, thus protecting the liver tissue of rats [13]. Studies have shown that the polyphenol components contained in Bowl tea are different from those in green tea [14]. Bowl tea and green tea polyphenols may have different mechanisms on NAFLD, which is also an important topic in this study.

We observed the effect of Raw Bowl Tea polyphenols (RBTP) on NAFLD by inducing NAFLD in mice fed a high fat diet. The serum and liver tissues of NAFLD mice were analyzed, and the effects 
of RBTP on the markers of NAFLD were examined. At the same time, the effects of RBTP on the intestinal function and intestinal microecology of mice were further observed, and the role of RBTP in protecting the liver by regulating intestinal function and intestinal microecology was confirmed. In addition, the mechanism of RBTP was further elucidated by the composition analysis. This study comprehensively explained the mechanism of RBTP in preventing NAFLD by regulating intestinal function and microecology with its effective compounds. This study accumulates the theoretical basis for the further rational application of RBTP and lays the foundation for future clinical research.

\section{Materials and Methods}

\subsection{Extraction of RBTP}

A $500 \mathrm{~g}$ raw Bowl tea (RBT) sample was crushed into powder, and $50 \mathrm{~mL} 45 \%$ (volume ratio) ethanol solution was added to the RBT powder and extracted at $90{ }^{\circ} \mathrm{C}$ for $30 \mathrm{~min}$. After a repeated extraction, two extracts were combined, and the $\mathrm{pH}$ of the total extract was adjusted to 6.0. Then $800 \mathrm{~mL}$ mixed precipitant of $\mathrm{AlCl}_{3}$ (30 g, Tianjin Damao Chemical Reagent Factory, Tianjin, China) and $\mathrm{ZnCl}_{2}$ (60 g, Tianjin Damao Chemical Reagent Factory, Tianjin, China) was added to the extract for precipitation, and then the mixture was centrifuged at $3000 \times \mathrm{g}$ for $10 \mathrm{~min}$. $1000 \mathrm{~mL}$ hydrochloric acid (12\%, volume ratio, Tianjin Damao Chemical Reagent Factory, Tianjin, China) was added to the collected precipitation for transsolution. The supernatant was separated, and $50 \mathrm{~mL}$ ethyl acetate (Tianjin Damao Chemical Reagent Factory, Tianjin, China) was added twice for extraction. Finally, the extract was subjected to rotary evaporation to obtain RBTP [15].

\subsection{Determination of RBTP Composition}

Two $\mathrm{mL}$ of chromatographic grade methanol were added separately to the following polyphenolic compounds: (-)-epicatechin gallate (ECG), gallic acid, (-)-epigallocatechin (EGC), caffeine, (-)-epigallocatechin gallate (EGCG), (-)-gallocatechin gallate (GCG), L-epicatechin (EC), and catechin standards. Each accurately weighed reference substance was fully dissolved by oscillation to obtain the standard solution. $10 \mathrm{~mL}$ of chromatographic grade methanol was added to accurately weighed $5 \mathrm{mg}$ dried tea polyphenol extract, and was dissolved by oscillation. Samples were filtered with a microporous membrane $(0.22 \mu \mathrm{m})$ to obtain the test solution. Component analysis was carried out under the following chromatographic conditions: Mobile phase A was methanol; mobile phase B was $0.1 \%$ formic acid; mobile phase $C$ was acetonitrile; the flow rate was set at $0.6 \mathrm{~mL} / \mathrm{min}$; chromatographic column was Accucore PFP $(2.6 \mu \mathrm{m}, 50 \times 2.1 \mathrm{~mm})$; the column temperature was $30^{\circ} \mathrm{C}$; wavelength was $280 \mathrm{~nm}$; injection volume was $10 \mu \mathrm{L}$. At the same time, the chromatographic peak area of each component was recorded to analyze the content of each component (Ultimate3000; Thermo Fisher Scientific, Inc., Waltham, MA, USA).

\subsection{Culture and Induced Differentiation of 3T3-L1 Preadipocytes}

3T3-L1 preadipocytes (American Type Culture Collection, Manassas, VA, USA) were cultured with DMEM (Thermo Fisher Scientific, Waltham, MA, USA) containing $10 \%$ calf serum at $37^{\circ} \mathrm{C}$ and $5 \%$ $\mathrm{CO}_{2}$. When the cells were in good condition, they were inoculated on the culture plate and cultured for $48 \mathrm{~h}$ with DMEM containing $0.5 \mathrm{mmol} / \mathrm{L}$ isobutyl-3-methylxanthine, $0.25 \mu \mathrm{mol} / \mathrm{L}$ dexamethasone, $10 \mu \mathrm{g} / \mathrm{mL}$ insulin and $10 \%$ fetal bovine serum. Subsequently, DMEM medium containing $10 \%$ fetal bovine serum was used for further culture. The medium was changed every 2 days. After 8-12 days of differentiation, more than $85 \%$ of 3T3-L1 cells showed adipocyte phenotypes, which could be used in the experiment.

\subsection{Effect of RBTP on the Proliferation of 3T3-L1 Preadipocytes Detected by XTT Assay}

The 3T3-L1 preadipocytes were inoculated into 96-well plates at a cell concentration of $1.5 \times 10^{4} / \mathrm{mL}$, $100 \mu \mathrm{L}$ medium was added to each well. After cell adherence, $200 \mu \mathrm{g} / \mathrm{mL}$ of RBTP, ECG, gallic acid, 
EGC, caffeine, EGCG, GCG, EC and catechin were added to intervention culture for $72 \mathrm{~h}$. $\mathrm{OD}_{570}$ values of each group were detected by the XTT method, and the number of cells was calculated.

\subsection{Establishment of NAFLD Mouse Model}

Fifty 8-week-old SPF grade C57BL/6N mice (half male and half female, Chongqing Medical University, Chongqing, China) were fed for $1 \mathrm{w}$ to adapt to the environment, and were divided into five groups on average: Normal group, model group, RBTP low-concentration gavage group (RBTP-L group), RBTP high-concentration gavage group (RBTP-H group), and bezafibrate gavage group (bezafibrate group), with 10 mice in each group. Mice in the normal group were fed normal maintenance foods and drinking water; mice in the other groups were fed a D12492 high-fat diet, while mice in the RBTP-L and RBTP-H groups were intragastrically administered with RBTP at the concentrations of 50 and $100 \mathrm{mg} / \mathrm{kg}$ once a day, respectively. Mice in the bezafibrate group were intragastrically administered with bezafibrate at the concentration of $100 \mathrm{mg} / \mathrm{kg}$ daily. After $12 \mathrm{w}$, all mice fasted for $24 \mathrm{~h}$ and then were sacrificed by cervical dislocation [16]. Blood was taken from the heart and liver; epididymal fat and small intestine tissues were collected for subsequent experiments. The liver tissue was weighed and a liver index was calculated by the formula: Liver weight (g)/mouse body weight $(\mathrm{kg}) \times 100$. This study was conducted in accordance with the Declaration of Helsinki, and the protocol was approved by the Ethics Committee of Chongqing Collaborative Innovation Center for Functional Food (201807004B), Chongqing, China.

\subsection{Determination of Serum Biochemical Indicators of ALT, AST, AKP, TC, TG, LDL-C, D-LA, DAO, and LPS}

The obtained mouse blood was centrifuged at $4000 \times \mathrm{g}$ for $10 \mathrm{~min}$, and the supernatant was collected. The serum levels of ALT, AST, AKP, TC, TG, HDL-C, LDL-C, D-LA, DAO, and LPS of the mice were determined by kit instructions (Nanjing Jiancheng Bioengineering Institute, Nanjing, Jiangsu, China).

\subsection{Determination of Liver Tissue Biochemical Indicators of $D-L A, D A O$, and LPS}

Nine $\mathrm{mL}$ of cold saline was added to $1 \mathrm{~g}$ of liver tissue, which was homogenized until no fibrous granules were found, and the supernatant was obtained after centrifugation $(4000 \times g)$. The liver tissue levels of D-LA, DAO, and LPS of the mice were determined by kit instructions (Nanjing Jiancheng Bioengineering Institute, Nanjing, Jiangsu, China).

\subsection{Determination of Liver Tissue of ROS}

One $\mathrm{g}$ of liver tissue was suspended in buffer containing $20 \mathrm{mmol} / \mathrm{L}$ Tir- $\mathrm{HCl}(\mathrm{pH} \mathrm{7.4)}$, $20 \mathrm{mmol} / \mathrm{L} \mathrm{NaH}_{2} \mathrm{PO}_{4}, 5 \mathrm{mmol} / \mathrm{L} \mathrm{MgCl}, 130 \mathrm{mmol} / \mathrm{L} \mathrm{KCl}$, and $30 \mathrm{mmol} / \mathrm{L}$ glucose, ground uniformly, centrifuged at $4{ }^{\circ} \mathrm{C}, 6000 \mathrm{rpm}$ for $15 \mathrm{~min}$, and the supernatant was removed. DCFH-DA $\left(2^{\prime}, 7^{\prime}\right.$-dichlorodihydrofluorescein diacetate) was added to the supernatant and incubated at $37^{\circ} \mathrm{C}$ for $15 \mathrm{~min}$, then the reaction was terminated by adding $1 \mu \mathrm{mol} / \mathrm{L}$ of $\mathrm{H}_{2} \mathrm{O}_{2}$. The absorbance value was determined by fluorescence spectrophotometer (Evolution 220, Thermo Fisher Scientific, Waltham, MA, USA), and the relative level of ROS was expressed by fluorescence signal intensity.

\subsection{Determination of Serum Cytokines IL-1 $\beta, I L-4, I L-6, I L-10, T N F-\alpha$, and INF- $\gamma$}

The obtained mouse blood was centrifuged at $4000 \times g$ for $10 \mathrm{~min}$, and the supernatant was collected. The serum levels of cytokines IL-6, IL-1 $\beta$, TNF- $\alpha$, INF- $\gamma$, IL-4, and IL-10 were determined by kit instructions (Abcam, Cambridge, MA, USA).

\subsection{Pathological Observation of Liver, Epididymal Fat, and Small Intestine Tissues}

Liver, epididymal fat, and the posterior part of the small intestine tissue at the size of $0.5 \mathrm{~cm}^{2}$ were collected and fixed in 10\% formalin solution for $48 \mathrm{~h}$. The liver and epididymal fat tissues were 
dehydrated, cleared, waxed, embedded, sectioned, and stained with H\&E. The morphological changes were observed under optical microscope (BX43; Olympus, Tokyo, Japan).

\subsection{Quantitative PCR (qPCR) Assay}

The liver tissue, small intestine tissue, and feces of the mice were pulverized. RNAzol (Invitrogen, Carlsbad, CA, USA) was used to extract total RNA from the sample, and then the concentration of extracted total RNA was diluted to $1 \mu \mathrm{g} / \mu \mathrm{L} .5 \mu \mathrm{L}$ of the diluted total RNA solution was removed for reverse transcription, which was carried out according to the instruction of reverse transcription kit to obtain the cDNA template. $2 \mu \mathrm{L}$ of cDNA template was mixed with $10 \mu \mathrm{L}$ of SYBR Green PCR Master Mix (Thermo Fisher Scientific) and $1 \mu \mathrm{L}$ upstream and downstream primers (Table 1). The system was reacted at $95^{\circ} \mathrm{C}$ for $60 \mathrm{~s}$; then at the conditions of $95^{\circ} \mathrm{C}$ for $15 \mathrm{~s}, 55^{\circ} \mathrm{C}$ for $30 \mathrm{~s}, 72{ }^{\circ} \mathrm{C}$ for $35 \mathrm{~s}$, for 40 cycles. Finally, the DNA was detected at $95^{\circ} \mathrm{C}$ for $30 \mathrm{~s}$ and $5{ }^{\circ} \mathrm{C}$ for $35 \mathrm{~s}$; GAPDH was used as the internal reference (StepOnePlus Real-Time PCR System; Thermo Fisher Scientific). The $2^{-\Delta \Delta C t}$ method was used to determine the level of relative gene expression [17].

Table 1. Sequences of primers used in this study.

\begin{tabular}{|c|c|}
\hline Gene Name & Sequence \\
\hline PPAR- $\alpha$ & $\begin{array}{l}\text { Forward: 5'-CCTCAGGGTACCACTACGGAGT-3' } \\
\text { Reverse: 5'-GCCGAATAGTTCGCCGAA-3' }\end{array}$ \\
\hline PPAR- $\gamma$ & $\begin{array}{l}\text { Forward: 5'-AGGCCGAGAAGGAGAAGCTGTTG-3' } \\
\text { Reverse: 5'-TGGCCACCTCTTTGCTGTGCTC-3' }\end{array}$ \\
\hline CYP7A1 & $\begin{array}{c}\text { Forward: 5'-AGCAACTAAACAACCTGCCAGTACTA-3' } \\
\text { Reverse: 5'-GTCCGGATATTCAAGGATGCA-3' }\end{array}$ \\
\hline CPT1 & $\begin{array}{c}\text { Forward: 5'-AAAGATCAATCGGACCCTAGACA-3' } \\
\text { Reverse: 5'-CAGCGAGTAGCGCATAGTCA-3' }\end{array}$ \\
\hline LPL & $\begin{array}{l}\text { Forward: 5'-AGGGCTCTGCCTGAGTTGTA-3' } \\
\text { Reverse: 5'-AGAAATCTCGAAGGCCTGGT-3' }\end{array}$ \\
\hline $\mathrm{C} / \mathrm{EBP} \alpha$ & $\begin{array}{l}\text { Forward: 5'-TGGACAAGAACAGCAACGAGTAC-3' } \\
\text { Reverse: 5'-GCAGTTGCCCATGGCCTTGAC-3' }\end{array}$ \\
\hline CD36 & $\begin{array}{l}\text { Forward: 5'-GATGACGTGGCAAAGAACAG-3' } \\
\text { Reverse: 5'-TCCTCGGGGTCCTGAGTTAT-3' }\end{array}$ \\
\hline Occludin & $\begin{array}{l}\text { Forward: 5'-TGTGGATAAGGAACACATTTATGA-3' } \\
\text { Reverse: 5'-CAGACACATTTTTAACCCACTCTTCA-3' }\end{array}$ \\
\hline $\mathrm{ZO}-1$ & $\begin{array}{l}\text { Forward: 5'-TGAACGCTCTCATAAGCTTCGTAA-3' } \\
\text { Reverse: 5'-ACCGTACCAACCATCATTCATTG-3' }\end{array}$ \\
\hline TNF- $\alpha$ & $\begin{array}{c}\text { Forward: 5'-CAGGCGGTGCCTATGTCTC-3' } \\
\text { Reverse: 5'-CGATCACCCCGAAGTTCAGTAG-3' }\end{array}$ \\
\hline \multirow{2}{*}{ Firmicutes } & Forward: 5'-TGAAACTYAAAGGAATTGACG-3' \\
\hline & Reverse: 5'-ACCATGCACCACCTGTC-3' \\
\hline \multirow{2}{*}{ Bacteroides } & Forward: 5'-CRAACAGAATTAGATACCCT-3' \\
\hline & Reverse: 5'-GGTAAGGTTCCTCGCGTAT-3' \\
\hline \multirow{2}{*}{ Akkermansia } & Forward: 5'-GGAGATTACTGCCCTGGCTCCTA-3' \\
\hline & Reverse: 5'-CACTCATCGTACTCCTGCTTGTTGCTG-3' \\
\hline \multirow{2}{*}{ GAPDH } & Forward: 5'-ACCCAGAAGACTGTGGATGG-3' \\
\hline & Reverse: 5'-ACACATTGGGGGTAGGAACA-3' \\
\hline
\end{tabular}

PPAR- $\alpha$ : peroxisome proliferator-activated receptor-alpha; PPAR- $\gamma$ : peroxisome proliferator-activated receptor-gamma; CYP7A1: cholesterol 7 alpha-hydroxylase; CPT1: carnitine palmitoyltransferase 1; C/EBP $\alpha$ : CCAAT enhancer-binding protein alpha; CD36: cluster of differentiation 36; ZO-1: zonula occludens-1; TNF- $\alpha$ : tumor necrosis factor alpha; GAPDH: glyceraldehyde-3-phosphate dehydrogenase.

\subsection{Western Blot Analysis}

$100 \mathrm{mg}$ of each liver and epididymal fat tissue samples were homogenized with $1 \mathrm{~mL}$ of RIPA and $10 \mu \mathrm{L}$ of PMSF, then centrifuged at $12,000 \times g$ at $4{ }^{\circ} \mathrm{C}$ for $4 \mathrm{~min}$. The intermediate protein layer solution 
was removed, and the BCA protein quantification kit was used for protein quantification. Samples of each group were diluted to $50 \mu \mathrm{g} / \mathrm{mL}$, and the diluted protein was mixed with Sample Buffer at the ratio of $4: 1$ and heated at $100^{\circ} \mathrm{C}$ for 5 min. Then Mixing Acrylamide, Resolving Buffer, Starcking Buffer, distilled water, 10\% APS, and TEMED were mixed in proportion to make SDS-PAGE separation gel and stacking gel, and poured into the gel plate. The Prestained Protein Ladder and the sample were separately added into the sample wells of the gel plate, and the protein-loaded SDS-PAGE gel was subjected to vertical gel electrophoresis for $50 \mathrm{~min}$. The polyvinylidene difluoride (PVDF) membrane was activated by methanol for $1 \mathrm{~min}$ and then transmembrane was performed. After that, the PVDF membrane was blocked by $5 \%$ fat-free milk containing TBST solution for $1 \mathrm{~h}$. After blocking, the PVDF membrane was washed by TBST. The first antibody was incubated at $25^{\circ} \mathrm{C}$ for $2 \mathrm{~h}$, and the second antibody was incubated at $25^{\circ} \mathrm{C}$ for $1 \mathrm{~h}$. Finally, Supersignal West Pico PLUS was used to fill the PVDF membrane and was placed in the iBright FL1000 (Thermo Fisher Scientific) for observation [18].

\subsection{Statistical Analysis}

The serum and tissue assays of each mouse were performed in three parallel experiments and the average value was calculated. SAS9.1 statistical software (Version, Company, City, Country) was used for data analysis and one-way ANOVA method was used to analyze whether there were significant differences among groups of data at the level of $p<0.05$ [18].

\section{Results}

\subsection{Composition Analysis of RBTP}

HPLC analysis showed that RBTP contained seven polyphenolic compounds (Figure 1), which were gallic acid, (-)-epigallocatechin (EGC), catechin, L-epicatechin (EC), (-)-epigallocatechin gallate (EGCG), (-)-gallocatechin gallate (GCG), and (-)-epicatechin gallate (ECG). Because caffeine was not easily separated in the extraction of natural polyphenols, a small amount of caffeine remained in RBTP. Quantitative analysis showed that the sequence of RBTP polyphenol contents were as following: ECG $>$ EGC > EGCG > catechin > gallic acid > EC = GCG > caffeine (Table 2).
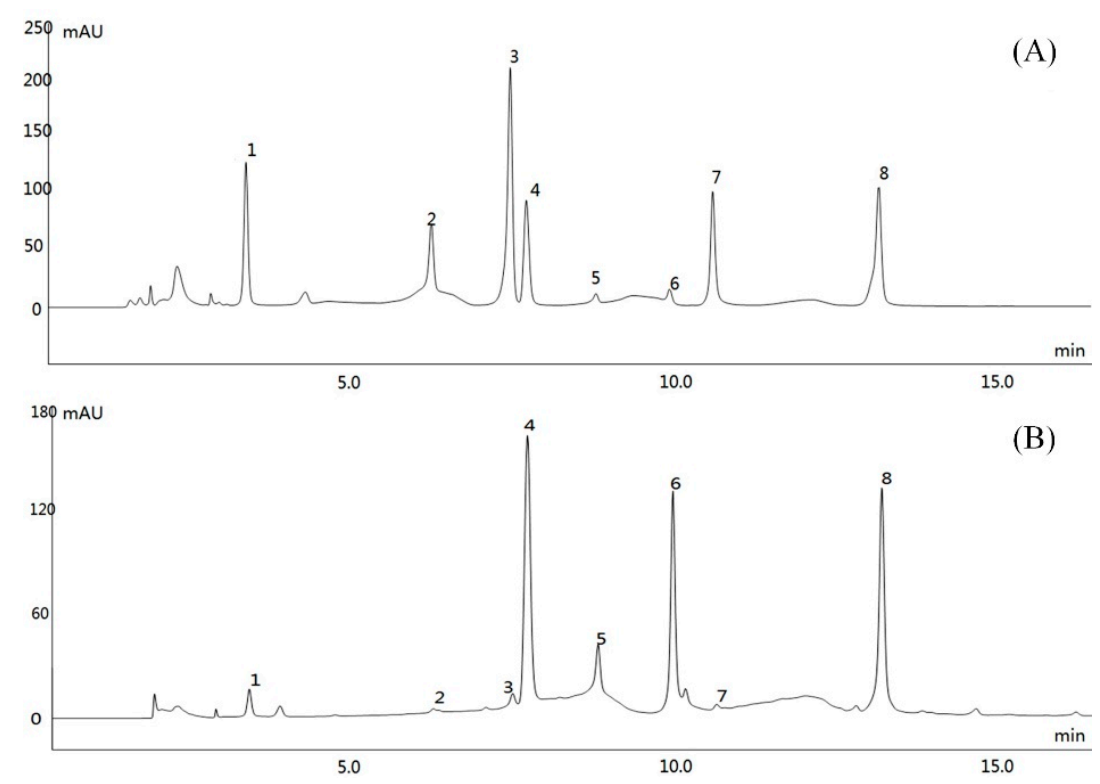

Figure 1. Polyphenol constituents of raw Bowl tea. (A) Standard chromatograms; (B) Polyphenols of raw Bowl tea chromatograms. 1: gallic acid, 2: (-)-epigallocatechin (EGC); 3: catechin; 4: caffeine; 5: L-epicatechin (EC); 6: (-)-epigallocatechin gallate (EGCG); 7: (-)-gallocatechin gallate (GCG); 8: (-)-epicatechin gallate (ECG). 
Table 2. Contents of polyphenols of small-leaved Kuding tea.

\begin{tabular}{cc}
\hline Polyphenol & Content $(\mathbf{m g} / \mathbf{g})$ \\
\hline Gallic acid & 15.0 \\
(-)-epigallocatechin & 107.5 \\
Catechin & 22.5 \\
Caffeine & 2.5 \\
L-Epicatechin & 7.5 \\
(-)-epigallocatechin gallate & 47.5 \\
(-)-gallocatechin gallate & 7.5 \\
(-)-epicatechin gallate & 230.0 \\
\hline
\end{tabular}

\subsection{Effect of Samples on Proliferation of 3T3-L1 Preadipocytes}

The results showed that gallic acid, (-)-epigallocatechin, catechin, caffeine, L-epicatechin, (-)-epigallocatechin gallate, (-)-gallocatechin gallate, (-)-epicatechin gallate and RBTP could significantly $(p<0.05)$ inhibit the proliferation of 3T3-L1 preadipocytes (Table 3), and the effects of (-)-epigallocatechin and (-)-epigallocatechin gallate were better than those of RBTP, while the effects of other compounds were lower than that of RBTP.

Table 3. Effect of samples on proliferation of 3T3-L1 preadipocytes.

\begin{tabular}{cc}
\hline Sample $(\mathbf{2 0 0} \boldsymbol{\mu g} / \mathbf{m L})$ & Cell Counts $\left.\mathbf{( 1 0 ^ { 4 }} / \mathbf{m L}\right)$ \\
\hline Untreatment & $14.63 \pm 0.42^{\mathrm{a}}$ \\
RBTP & $8.64 \pm 0.53^{\mathrm{d}}$ \\
Gallic acid & $12.71 \pm 0.46^{\mathrm{b}}$ \\
(-)-epigallocatechin & $7.44 \pm 0.52^{\mathrm{e}}$ \\
Catechin & $8.61 \pm 0.36^{\mathrm{d}}$ \\
Caffeine & $9.66 \pm 0.50^{\mathrm{c}}$ \\
L-Epicatechin & $9.29 \pm 0.44^{\mathrm{c}}$ \\
(-)-epigallocatechin gallate & $6.82 \pm 0.45^{\mathrm{f}}$ \\
(-)-gallocatechin gallate & $12.51 \pm 0.58^{\mathrm{b}}$ \\
(-)-epicatechin gallate & $9.62 \pm 0.49^{\mathrm{c}}$ \\
\hline
\end{tabular}

Values presented are the mean \pm standard deviation $(N=6 /$ group $) .{ }^{a-f}$ Mean values with different letters over the same row are significantly different $(p<0.05)$ according to Duncan's multiple range test. RBTP: polyphenol of raw Bowl tea.

\subsection{Liver Index of Mice}

Mice in the normal group had the lowest body weight, liver weight, and liver index, while those in the model group had the highest indices (Table 4). After the administration of RBTP and bezafibrate, the body weight, liver weight, and liver index of all NAFLD mice decreased. A high concentration of RBTP (RBTP-H) showed the most significant reducing effect on the body weight, liver weight, and liver index, making these indices close to those of the normal group.

Table 4. The liver index of mice with nonalcoholic fatty liver disease.

\begin{tabular}{cccc}
\hline Group & Body Weight & Live Weight & Liver Index \\
\hline Normal & $31.15 \pm 1.63^{\mathrm{b}}$ & $1.37 \pm 0.14^{\mathrm{b}}$ & $4.40 \pm 0.15^{\mathrm{c}}$ \\
Model & $42.32 \pm 2.79^{\mathrm{a}}$ & $2.45 \pm 0.52^{\mathrm{a}}$ & $5.79 \pm 0.35^{\mathrm{a}}$ \\
RBTP-L & $40.85 \pm 2.81^{\mathrm{a}}$ & $2.12 \pm 0.33^{\mathrm{a}}$ & $5.19 \pm 0.23^{\mathrm{ab}}$ \\
RBTP-H & $34.60 \pm 2.05^{\mathrm{b}}$ & $1.67 \pm 0.23^{\mathrm{ab}}$ & $4.83 \pm 0.26^{\mathrm{b}}$ \\
Bezafibrate & $37.39 \pm 2.14^{\mathrm{ab}}$ & $1.86 \pm 0.18^{\mathrm{ab}}$ & $4.97 \pm 0.18^{\mathrm{ab}}$ \\
\hline
\end{tabular}

Values presented are the mean \pm standard deviation ( $N=10$ /group). ${ }^{a-c}$ Mean values with different letters over the same column are significantly different $(p<0.05)$ according to Duncan's multiple range test. RBTP-L: mice treated with low concentrations of polyphenols of raw Bowl tea $(50 \mathrm{mg} / \mathrm{kg})$; RBTP-H: mice treated with high concentrations of polyphenols of raw Bowl tea (100 mg/kg); Bezafibrate: mice treated with bezafibrate $(100 \mathrm{mg} / \mathrm{kg})$. 


\subsection{Serum Levels of Biochemical Indicators of ALT, AST, AKP, TC, TG, HDL-C, and LDL-C in Mice}

Table 5 indicates that the levels of ALT, AST, AKP, TC, TG, and LDL-C in the serum of healthy mice (normal group) were the lowest, while HDL-C levels were the highest. Mice with NAFLD (model group) showed a contrary trend. The serum levels of ALT, AST, AKP, TC, TG, and LDL-C were the highest and the HDL-C level was the lowest in the model group. After the administration of RBTP and bezafibrate, the levels of ALT, AST, AKP, TC, TG, and LDL-C in NAFLD mice decreased, while the level of HDL-C increased. The effect of RBTP-H was stronger than that of bezafibrate and RBTP-L.

Table 5. The levels of ALT, AST, AKP, TC, TG, HDL-C, and LDL-C in serum of mice.

\begin{tabular}{cccccc}
\hline Group & Normal & Model & RBTP-L & RBTP-H & Bezafibrate \\
\hline ALT (U/L) & $16.02 \pm 1.14^{\mathrm{e}}$ & $51.62 \pm 2.45^{\mathrm{a}}$ & $35.70 \pm 1.73^{\mathrm{b}}$ & $25.84 \pm 1.66^{\mathrm{d}}$ & $31.12 \pm 1.52^{\mathrm{c}}$ \\
AST (U/L) & $10.26 \pm 2.31^{\mathrm{e}}$ & $53.35 \pm 3.15^{\mathrm{a}}$ & $40.82 \pm 2.74^{\mathrm{b}}$ & $17.36 \pm 1.89^{\mathrm{d}}$ & $24.31 \pm 2.30^{\mathrm{c}}$ \\
AKP (U/L) & $33.52 \pm 6.71^{\mathrm{e}}$ & $87.36 \pm 7.03^{\mathrm{a}}$ & $63.05 \pm 4.18^{\mathrm{b}}$ & $45.96 \pm 3.24^{\mathrm{d}}$ & $56.37 \pm 4.02^{\mathrm{c}}$ \\
TC (mmol/L) & $1.87 \pm 0.21^{\mathrm{e}}$ & $5.32 \pm 0.36^{\mathrm{a}}$ & $4.01 \pm 0.23^{\mathrm{b}}$ & $2.57 \pm 0.31^{\mathrm{d}}$ & $3.11^{\mathrm{a}} \pm 0.27^{\mathrm{c}}$ \\
TG (mmol/L) & $0.55 \pm 0.04^{\mathrm{e}}$ & $1.62 \pm 0.17^{\mathrm{a}}$ & $1.23 \pm 0.13^{\mathrm{b}}$ & $0.71 \pm 0.05^{\mathrm{d}}$ & $0.92^{\mathrm{a}} \pm 0.08^{\mathrm{c}}$ \\
HDL-C (mmol/L) & $1.11 \pm 0.15^{\mathrm{a}}$ & $0.29 \pm 0.05^{\mathrm{e}}$ & $0.53 \pm 0.06^{\mathrm{d}}$ & $0.87 \pm 0.05^{\mathrm{b}}$ & $0.70 \pm 0.04^{\mathrm{c}}$ \\
LDL-C (mmol/L) & $0.47 \pm 0.03^{\mathrm{e}}$ & $1.33 \pm 0.12^{\mathrm{a}}$ & $1.01 \pm 0.07^{\mathrm{b}}$ & $0.63 \pm 0.04^{\mathrm{d}}$ & $0.88^{\mathrm{m}} \pm 0.07^{\mathrm{c}}$ \\
\hline
\end{tabular}

Values presented are the mean \pm standard deviation $\left(N=10\right.$ /group). ${ }^{a-e}$ Mean values with different letters over the same row are significantly different $(p<0.05)$ according to Duncan's multiple range test. RBTP-L: mice treated with low concentrations of polyphenols of raw Bowl tea $(50 \mathrm{mg} / \mathrm{kg})$; RBTP-H: mice treated with high concentrations of polyphenols of raw Bowl tea $(100 \mathrm{mg} / \mathrm{kg})$; Bezafibrate: mice treated with bezafibrate $(100 \mathrm{mg} / \mathrm{kg})$. ALT: alanine aminotransferase; AST: aspartate aminotransferase; AKP: alkaline phosphatase; TC: total cholesterol; TG: triglyceride; HDL-C: high density lipoprotein cholesterol; LDL-C: low density lipoprotein cholesterol.

\subsection{Serum and Liver Tissue Levels of D-LA, DAO, and LPS in Mice}

Tables 6 and 7 show that the normal group mice had the lowest D-LA, DAO, and LPS serum levels, and the model group mice had the highest D-LA, DAO, and LPS levels. RBTP-H could reduce the D-LA, DAO, and LPS levels compared to the model group, and the mice in the RBTP-H group showed the lower D-LA, DAO, and LPS levels than mice in the bezafibrate and RBTP-L groups.

Table 6. The levels of D-LA, DAO, and LPS in serum of mice.

\begin{tabular}{cccccc}
\hline Group & Normal & Model & RBTP-L & RBTP-H & Bezafibrate \\
\hline D-LA (mg/L) & $0.41 \pm 0.06^{\mathrm{e}}$ & $1.48 \pm 0.11^{\mathrm{a}}$ & $1.08 \pm 0.16^{\mathrm{b}}$ & $0.62 \pm 0.08^{\mathrm{d}}$ & $0.81 \pm 0.10^{\mathrm{c}}$ \\
DAO (pg/mL) & $81.03 \pm 6.32^{\mathrm{e}}$ & $225.61 \pm 11.03^{\mathrm{a}}$ & $145.63 \pm 8.97^{\mathrm{b}}$ & $110.39 \pm 5.44^{\mathrm{d}}$ & $189.27 \pm 12.52^{\mathrm{c}}$ \\
LPS (U/L) & $8.63 \pm 0.42^{\mathrm{e}}$ & $17.11 \pm 1.05^{\mathrm{a}}$ & $15.36 \pm 0.74^{\mathrm{d}}$ & $10.29 \pm 0.41^{\mathrm{b}}$ & $12.05 \pm 0.51^{\mathrm{c}}$ \\
\hline
\end{tabular}

Values presented are the mean \pm standard deviation ( $N=10$ /group). ${ }^{\mathrm{a}-\mathrm{e}}$ Mean values with different letters over the same row are significantly different $(p<0.05)$ according to Duncan's multiple range test. RBTP-L: mice treated with low concentrations of polyphenols of raw Bowl tea $(50 \mathrm{mg} / \mathrm{kg})$; RBTP-H: mice treated with high concentrations of polyphenols of raw Bowl tea $(100 \mathrm{mg} / \mathrm{kg})$; Bezafibrate: mice treated with bezafibrate $(100 \mathrm{mg} / \mathrm{kg})$. D-LA: D-Lactate; DAO: diamine oxidase; LPS: lipopolysaccharide.

Table 7. The levels of D-LA, DAO, and LPS in liver tissue of mice.

\begin{tabular}{cccccc}
\hline Group & Normal & Model & RBTP-L & RBTP-H & Bezafibrate \\
\hline D-LA (mg/gprot) & $0.26 \pm 0.03^{\mathrm{e}}$ & $0.63 \pm 0.04^{\mathrm{a}}$ & $0.53 \pm 0.03^{\mathrm{b}}$ & $0.37 \pm 0.02^{\mathrm{d}}$ & $0.44 \pm 0.03^{\mathrm{c}}$ \\
DAO (pg/gprot) & $12.51 \pm 3.86^{\mathrm{e}}$ & $59.71 \pm 4.32^{\mathrm{a}}$ & $48.12 \pm 2.33^{\mathrm{b}}$ & $20.36 \pm 3.02^{\mathrm{d}}$ & $31.08^{\mathrm{a}} \pm 3.67^{\mathrm{c}}$ \\
LPS (U/gprot) & $0.48 \pm 0.04^{\mathrm{e}}$ & $0.97 \pm 0.05^{\mathrm{a}}$ & $0.78 \pm 0.05^{\mathrm{d}}$ & $0.60 \pm 0.04^{\mathrm{b}}$ & $0.69 \pm 0.03^{\mathrm{c}}$ \\
\hline
\end{tabular}

Values presented are the mean \pm standard deviation ( $N=10$ /group). ${ }^{\text {a-e }}$ Mean values with different letters over the same row are significantly different $(p<0.05)$ according to Duncan's multiple range test. RBTP-L: mice treated with low concentrations of polyphenol of raw Bowl tea $(50 \mathrm{mg} / \mathrm{kg})$; RBTP-H: mice treated with high concentrations of polyphenol of raw Bowl tea $(100 \mathrm{mg} / \mathrm{kg})$; Bezafibrate: mice treated with bezafibrate $(100 \mathrm{mg} / \mathrm{kg})$. D-LA: D-Lactate; DAO: diamine oxidase; LPS: lipopolysaccharide.

\subsection{Serum Levels of Cytokines IL-1 $\beta$, IL-4, IL-6, IL-10, TNF- $\alpha$, and INF- $\gamma$ in Mice}

The serum cytokine detection assay showed that the serum levels of IL-1 $\beta$, IL-4, IL-6, IL-10, TNF- $\alpha$, and INF- $\gamma$ in normal mice were the lowest (Table 8), while these indices in the model group were 
the highest. Both RBTP and bezafibrate could alleviate the effects of NAFLD on mice. The serum levels of cytokines IL-1 $\beta$, IL-4, IL-6, IL-10, TNF- $\alpha$, and INF- $\gamma$ in NAFLD mice (the model group) were significantly lower than those in mice of the model group without non-intervention $(p<0.05)$, and RBTP-H had the strongest action to decrease these cytokines, which was significantly stronger than the drug bezafibrate.

Table 8. The levels of IL-1 $\beta$, IL-4, IL-6, IL-10, TNF- $\alpha$ and INF- $\gamma$ in serum of mice.

\begin{tabular}{cccccc}
\hline Group & Normal & Model & RBTP-L & RBTP-H & Bezafibrate \\
\hline IL-1 $\beta$ & $202.51 \pm 10.38^{\mathrm{e}}$ & $544.39 \pm 21.05^{\mathrm{a}}$ & $410.81 \pm 26.33^{\mathrm{b}}$ & $272.82 \pm 20.83^{\mathrm{d}}$ & $342.08 \pm 22.57^{\mathrm{c}}$ \\
IL-4 & $6.85 \pm 0.31^{\mathrm{e}}$ & $63.32 \pm 2.34^{\mathrm{a}}$ & $47.02 \pm 3.01^{\mathrm{b}}$ & $14.83 \pm 1.01^{\mathrm{d}}$ & $27.32 \pm 1.24^{\mathrm{c}}$ \\
IL-6 $(\mathrm{pg} / \mathrm{mL})$ & $43.10 \pm 3.65^{\mathrm{e}}$ & $145.98 \pm 7.82^{\mathrm{a}}$ & $114.29 \pm 4.38^{\mathrm{b}}$ & $67.08 \pm 2.17^{\mathrm{d}}$ & $85.33 \pm 5.12^{\mathrm{c}}$ \\
IL-10 $(\mathrm{pg} / \mathrm{mL})$ & $125.17 \pm 8.32^{\mathrm{e}}$ & $642.75 \pm 23.85^{\mathrm{a}}$ & $431.57 \pm 16.35^{\mathrm{b}}$ & $194.32 \pm 9.33^{\mathrm{d}}$ & $265.48 \pm 13.37^{\mathrm{c}}$ \\
TNF- $\alpha(\mathrm{pg} / \mathrm{mL})$ & $20.85 \pm 2.18^{\mathrm{e}}$ & $117.63 \pm 7.86^{\mathrm{a}}$ & $83.19 \pm 5.39^{\mathrm{b}}$ & $34.57 \pm 4.21^{\mathrm{d}}$ & $50.28 \pm 4.52^{\mathrm{c}}$ \\
INF- $\gamma(\mathrm{pg} / \mathrm{mL})$ & $14.38 \pm 1.71^{\mathrm{e}}$ & $104.58 \pm 6.63^{\mathrm{a}}$ & $70.25 \pm 3.88^{\mathrm{b}}$ & $23.47 \pm 2.20^{\mathrm{d}}$ & $37.82 \pm 3.17^{\mathrm{c}}$ \\
\hline
\end{tabular}

Values presented are the mean \pm standard deviation $\left(N=10\right.$ /group). ${ }^{\text {a-e }}$ Mean values with different letters over the same row are significantly different $(p<0.05)$ according to Duncan's multiple range test. RBTP-L: mice treated with low concentrations of polyphenols of raw Bowl tea $(50 \mathrm{mg} / \mathrm{kg})$; RBTP-H: mice treated with high concentrations of polyphenols of raw Bowl tea $(100 \mathrm{mg} / \mathrm{kg})$; Bezafibrate: mice treated with bezafibrate $(100 \mathrm{mg} / \mathrm{kg})$. IL- $1 \beta$ : interleukin 1 beta; IL-4: interleukin 4; IL-6: interleukin 6; IL-10: interleukin 10; TNF- $\alpha$ : tumor necrosis factor alpha; INF- $\gamma$ : interferon gamma.

\subsection{Liver Tissue Level ROS in Mice}

The mice in model group showed the strongest ROS level and RBTP and bezafibrate could reduce the levels of ROS, with RBTP-H having better reducing effects than bezafibrate and RBTP-L (Figure 2).

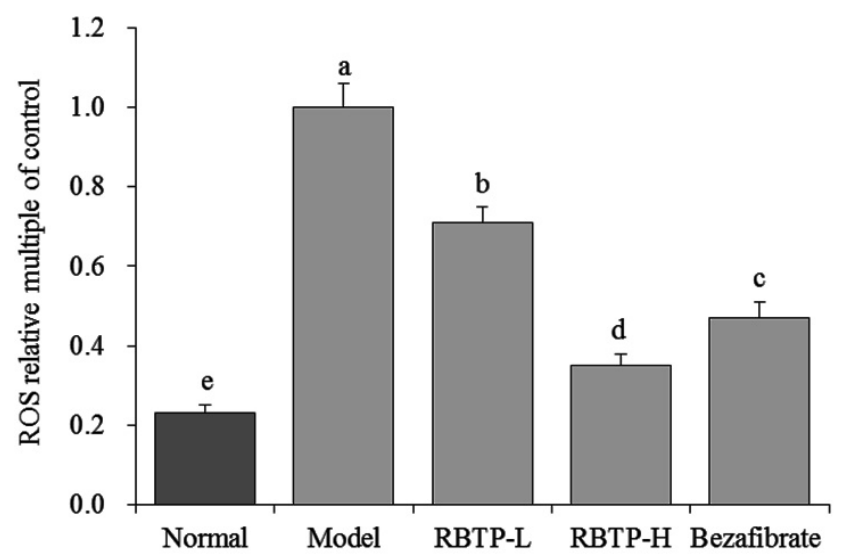

Figure 2. The ROS level of liver tissue in mice. ${ }^{a-e}$ Mean values with different letters in the bar are significantly different $(p<0.05)$ according to Duncan's multiple-range test. RBTP-L: mice treated with low concentrations of polyphenols of raw Bowl tea $(50 \mathrm{mg} / \mathrm{kg})$; RBTP-H: mice treated with high concentrations of polyphenols of raw Bowl tea $(100 \mathrm{mg} / \mathrm{kg})$; Bezafibrate: mice treated with bezafibrate $(100 \mathrm{mg} / \mathrm{kg})$.

\subsection{Pathological Observation of Liver, Epididymis, and Small Intestine Tissue of Mice}

The structure of hepatic lobules in normal mice was clear, the hepatocyte cord was arranged neatly, the cytoplasm of hepatocytes was observed to be fine granular, and there was no inflammatory cell infiltration in the portal canal area (Figure 3). The hepatocytes in mice of the model group had steatosis, and the lipid droplets in hepatocytes were diffuse. Granular accumulation could be seen, the lipid droplets increased obviously, and the inflammatory cells infiltrated significantly in interlobular and portal areas. In the RBTP-H, RBTP-L, and bezafibrate groups, the number of lipid droplets in the liver cells was significantly reduced, scattered, and sparse. The volume of lipid droplets was smaller, and the fat lesions were significantly alleviated. RBTP-H had stronger inhibitory effects on liver lesions than RBTP-L and bezafibrate did in NAFLD mice. 


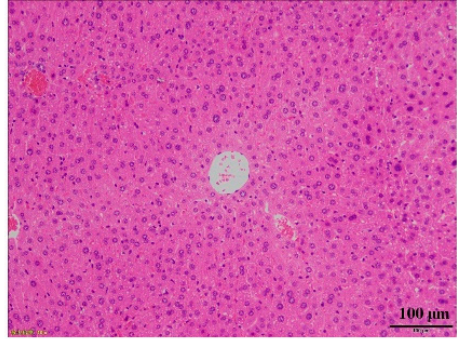

Normal

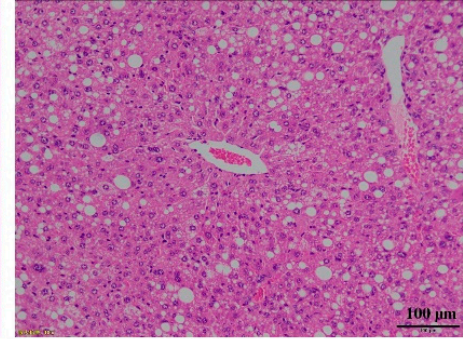

Model

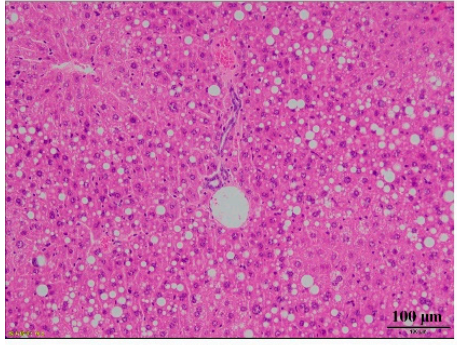

RBTP-L

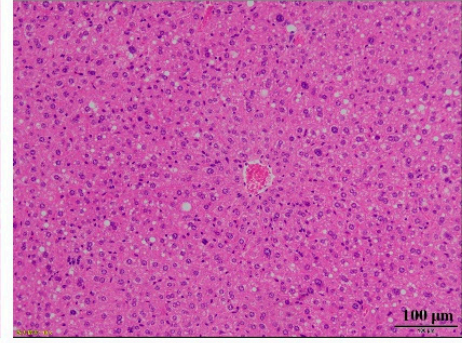

RBTP-H

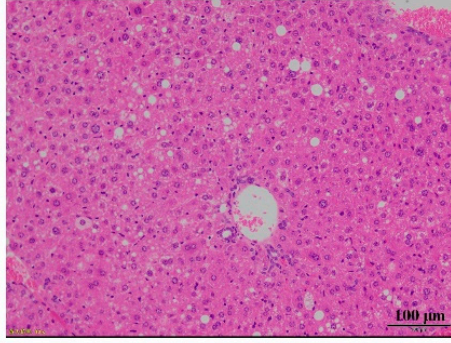

Bezafibrate

Figure 3. H\&E pathological observation of hepatic tissue in mice. Magnification 100x. RBTP-L: mice treated with low concentrations of polyphenols of raw Bowl tea (50 mg/kg); RBTP-H: mice treated with high concentrations of polyphenols of raw Bowl tea $(100 \mathrm{mg} / \mathrm{kg})$; Bezafibrate: mice treated with bezafibrate $(100 \mathrm{mg} / \mathrm{kg})$.

Adipocytes in epididymal fat tissue of mice in the normal group were smaller and were arranged neatly (Figure 4). In the model group, adipocytes became larger and the cell membrane became thinner, with two adjacent cells merging into one cell. Adipose tissue of mice fed RBTP and bezafibrate was denser compared to the model group. After RBTP-H was administered to NAFLD mice, the size of epididymal fat cells was similar to that of the normal group, which could significantly reduce the fat cell hypertrophy caused by a high-fat diet. The effect was stronger than that of RBTP-L and bezafibrate.

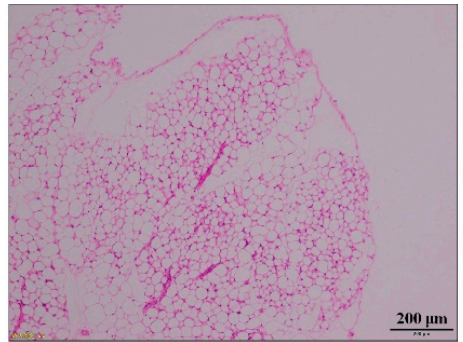

Normal

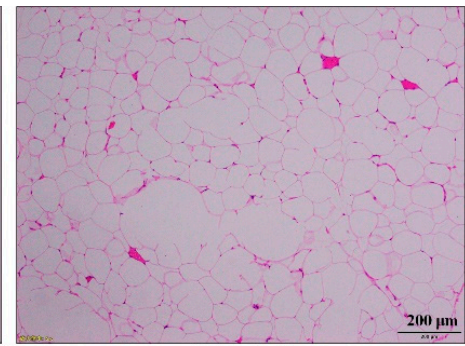

Model

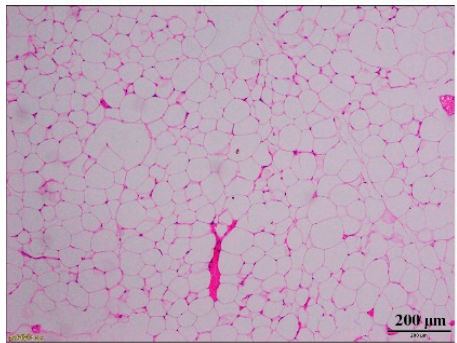

RBTP-L

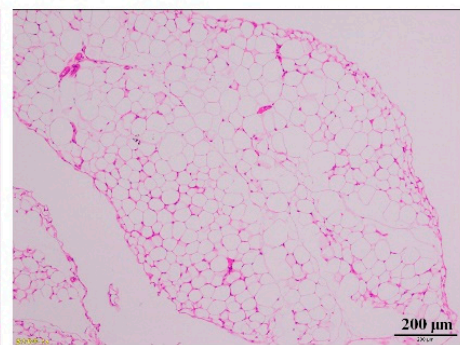

RBTP-H

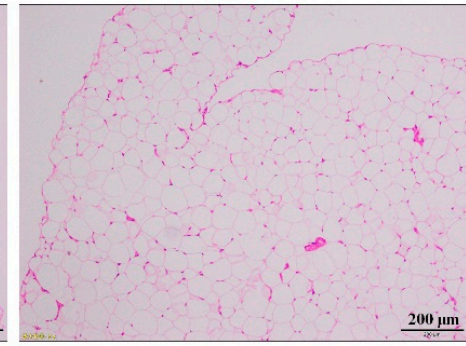

Bezafibrate

Figure 4. H\&E pathological observation of epididymal tissue in mice. Magnification 100×. RBTP-L: mice treated with low concentrations of polyphenols of raw Bowl tea (50 mg/kg); RBTP-H: mice treated with high concentrations of polyphenols of raw Bowl tea $(100 \mathrm{mg} / \mathrm{kg})$; Bezafibrate: mice treated with bezafibrate $(100 \mathrm{mg} / \mathrm{kg})$. 
Figure 5 shows no significant change in the morphology of intestinal mucosa in the normal group. The intestinal villi were arranged neatly, and there was no significant difference in mucosal epithelial thickness. In the model group, the height and width of villus decreased, and many villi were broken. Chronic inflammatory cell infiltration of monocytes and plasma cells appeared in the lamina propria of the intestinal mucosa of the model group. RBTP-H was able to minimize the damage of small intestine caused by NAFLD, and make the small intestine morphology closer to the normal group, which was better than the drug bezafibrate.

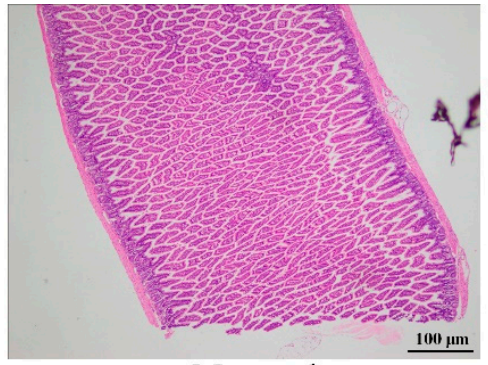

Normal

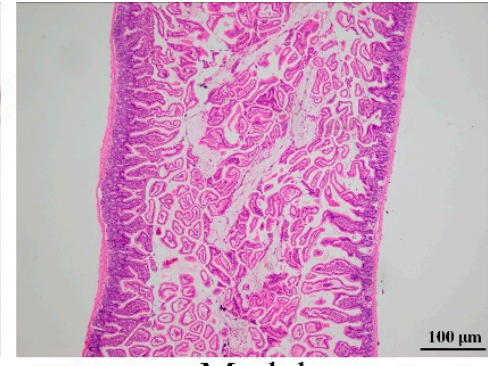

Model

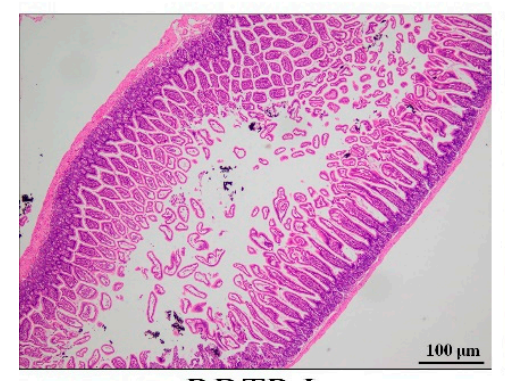

RBTP-L

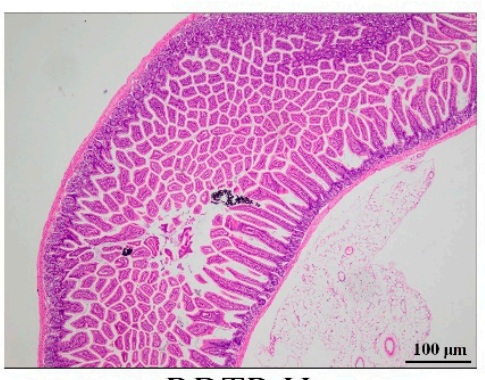

RBTP-H

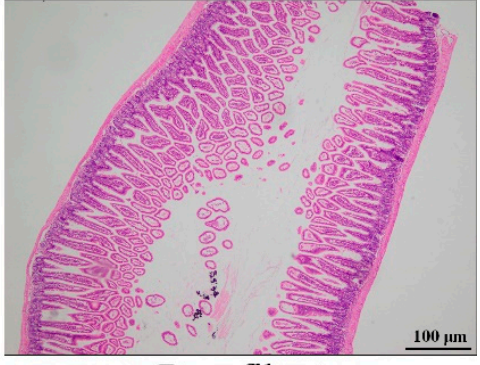

Bezafibrate

Figure 5. H\&E pathological observation of small intestine tissue in mice. Magnification 100×. RBTP-L: mice treated with low concentrations of polyphenols of raw Bowl tea (50 mg/kg); RBTP-H: mice treated with high concentrations of polyphenols of raw Bowl tea $(100 \mathrm{mg} / \mathrm{kg})$; Bezafibrate: mice treated with bezafibrate $(100 \mathrm{mg} / \mathrm{kg})$.

\subsection{Expression of RNA and Protein in Mouse Liver Tissue}

The mRNA and protein expressions of LPL, PPAR- $\alpha$, CYP7A1, and CPT1 were strongest in the liver tissues of normal mice, while the expression intensity of PPAR- $\gamma$ and C/EBP- $\alpha$ was weakest (Figure 6). The expression of LPL, PPAR- $\alpha$, CYP7A1, and CPT1 in liver tissue was significantly decreased $(p<0.05)$, while the expression of PPAR- $\gamma$ and C/EBP- $\alpha$ was significantly increased $(p<0.05)$ in mice induced by NAFLD. RBTP and bezafibrate were able to significantly inhibit the down-regulation of LPL, PPAR- $\alpha$, CYP7A1, and CPT1 expression and the up-regulation of PPAR- $\gamma$ and C/EBP- $\alpha$ in liver tissue of NAFLD mice $(p<0.05)$. The effect of RBTP-H was stronger and the expressions of PPAR- $\alpha$, PPAR- $\gamma$, CYP7A1, $\mathrm{CPT} 1, \mathrm{LPL}$, and C/EBP $\alpha$ in liver tissues of RBTP-H mice were close to those of normal mice. 
(A)
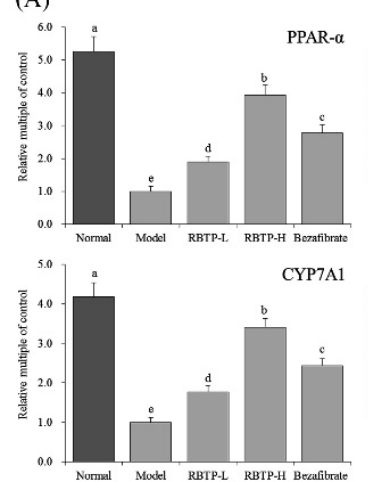

5.0

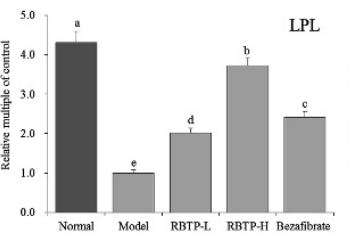

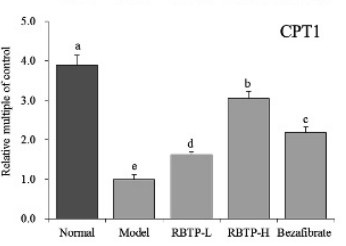

1.2

PT1

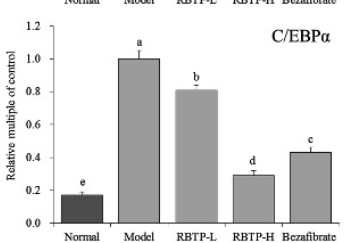

(B)
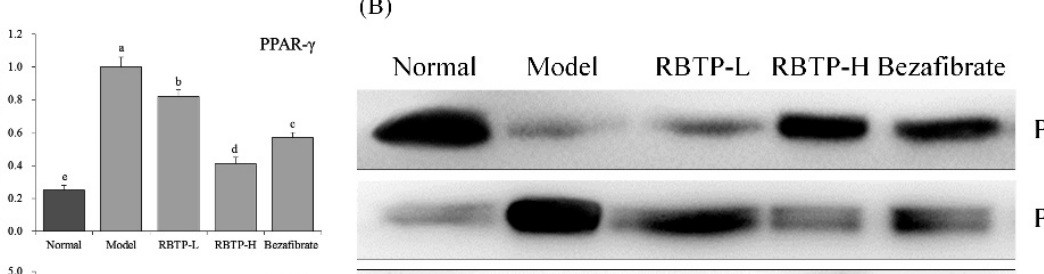

PPAR- $\alpha$

PPAR- $\gamma$
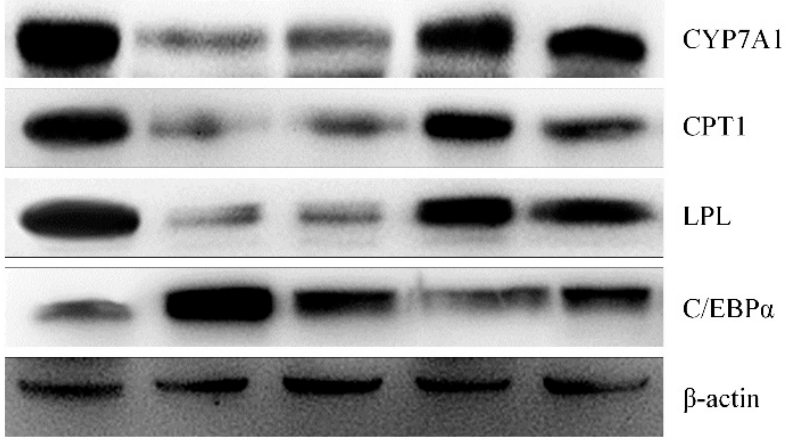

CPT1

LPL

$\mathrm{C} / \mathrm{EBP} \alpha$

$\beta$-actin

Figure 6. The PPAR- $\alpha$, PPAR- $\gamma$, CYP7A1, CPT1, LPL, and C/EBP $\alpha$ mRNA (A) and protein (B) expression in hepatic tissue of mice. ${ }^{\mathrm{a}-\mathrm{e}}$ Mean values with different letters in the bar are significantly different $(p<0.05)$ according to Duncan's multiple-range test. RBTP-L: mice treated with low concentrations of polyphenols of raw Bowl tea $(50 \mathrm{mg} / \mathrm{kg})$; RBTP-H: mice treated with high concentrations of polyphenols of raw Bowl tea $(100 \mathrm{mg} / \mathrm{kg})$; Bezafibrate: mice treated with bezafibrate $(100 \mathrm{mg} / \mathrm{kg})$.

\subsection{Expression of RNA and Protein in Mice Small Intestine Tissue}

Figure 7 indicates that the mRNA and protein expressions of occludin and ZO-1 in the small intestines of the model group were significantly $(p<0.05)$ lower than those of other groups, while the expression of CD36 and TNF- $\alpha$ were significantly stronger. RBTP and bezafibrate could significantly up-regulate occludin and ZO-1 expression, and down-regulate CD36 and TNF- $\alpha$ expressions in the small intestines of mice in the model group. RBTP-H was more effective than RBTP-L and bezafibrate. The effect of RBTP-H could make the expression of CD36, occludin, ZO-1, and TNF- $\alpha$ in the small intestines of NAFLD mice close to those of normal mice.
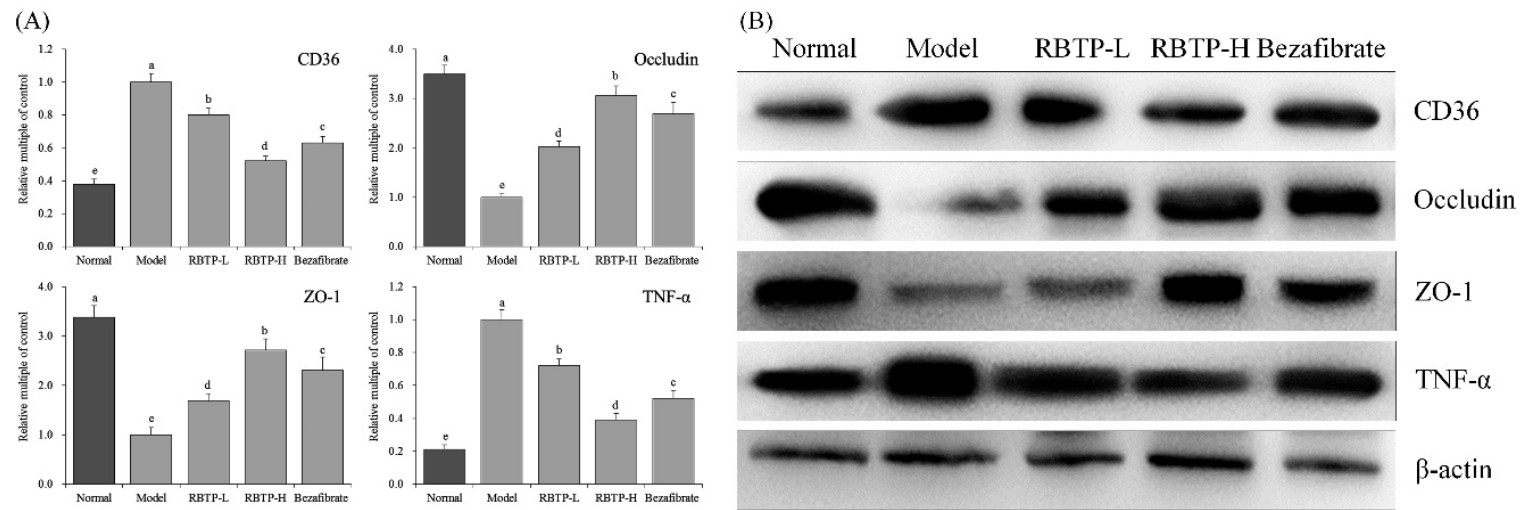

Figure 7. The CD36, occludin, ZO-1 and TNF- $\alpha$ mRNA (A) and protein (B) expression in small intestine tissue of mice. ${ }^{\mathrm{a}-\mathrm{e}}$ Mean values with different letters in the bar are significantly different $(p<0.05)$ according to Duncan's multiple-range test. RBTP-L: mice treated with low concentrations of polyphenols of raw Bowl tea (50 mg/kg); RBTP-H: mice treated with high concentrations of polyphenols of raw Bowl tea $(100 \mathrm{mg} / \mathrm{kg})$; Bezafibrate: mice treated with bezafibrate $(100 \mathrm{mg} / \mathrm{kg})$.

\subsection{Expression of Microbial RNA in Mice Feces}

The Firmicutes level in the feces of the model group was the highest, while the Bacteroides and Akkermansia levels were the lowest (Figure 8), and the proportion of Firmicutes/Bacteroides was also 
significantly higher than that of the other groups $(p<0.05)$. The levels of Firmicutes were decreased in the feces of RBTP-H, RBTP-L and bezafibrate mice, the levels of Bacteroides and Akkermansia increased, and the proportion of Firmicutes/Bacteroides also decreased significantly $(p<0.05)$. At the same time, RBTP-H showed stronger decreasing effects on the level of Firmicutes, stronger increasing levels of Bacteroides and Akkermansia, and a more significant reducing effect on the ratio of Firmicutes/Bacteroides in the feces of NAFLD mice compared to RBTP-L and bezafibrate, which made the microbial status in the feces close to healthy mice (normal group).
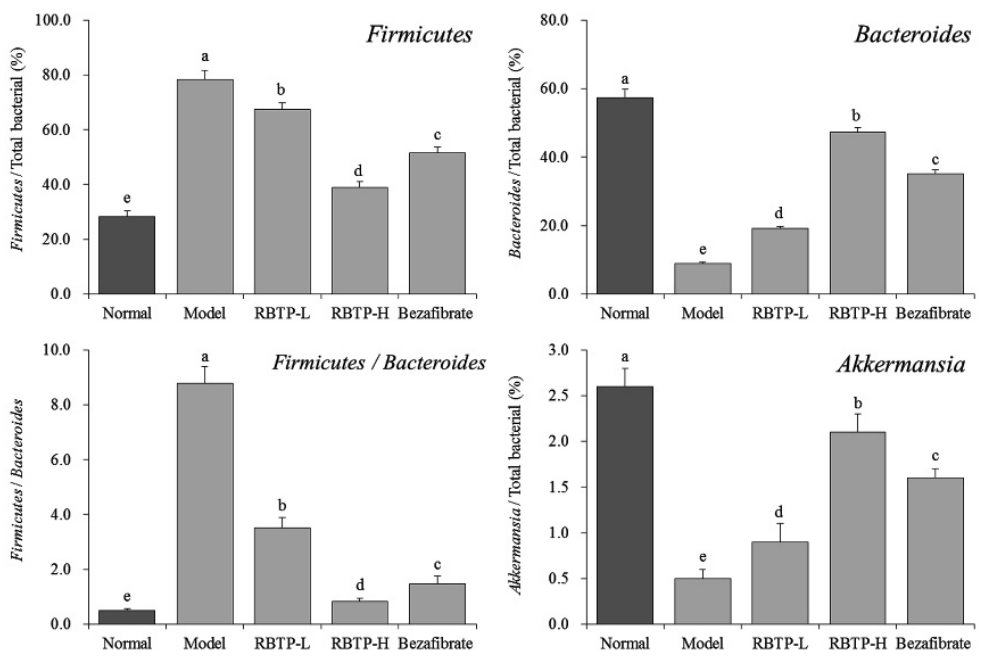

Figure 8. The mRNA expression in microorganisms in feces of mice. ${ }^{\mathrm{a}-\mathrm{e}}$ Mean values with different letters in the bar are significantly different $(p<0.05)$ according to Duncan's multiple-range test. RBTP-L: mice treated with low concentrations of polyphenols of raw Bowl tea (50 mg/kg); RBTP-H: mice treated with high concentrations of polyphenols of raw Bowl tea (100 mg/kg); Bezafibrate: mice treated with bezafibrate $(100 \mathrm{mg} / \mathrm{kg})$.

\section{Discussion}

In recent years, the incidence of various metabolic syndromes have increased every year with the rapid increase of the obese population globally. The incidence of NAFLD is 6-45\% in the general population, however, it can be as high as $90 \%$ in the severe obesity population [19]. NAFLD has become the most common cause of chronic liver disease in developed countries. Studies have shown that intestinal flora can cause intestinal dysfunction and abnormal lipid metabolism, which is closely related to the occurrence and development of NAFLD [20]. The intestinal flora of mice fed a high-sugar diet was also changed, showing a decrease in the number of Firmicutes and Bacteroides. High fructose intake could promote fat re-synthesis and inhibit fatty acid $\beta$ oxidation, leading to hepatic steatosis and the initiation of inflammatory reaction and, ultimately, the development of NAFLD [21,22]. In this study, we found that, in contrast to polyphenols extracted from green tea, those extracted from Tuocha tea have a preventive effect against nonalcoholic fatty liver disease.

Obesity is the main cause of nonalcoholic fatty liver disease. Thirty to fifty percent of obese people have fatty liver. Fatty liver is usually a reversible disease, and early prevention and diagnosis can normalize the liver [23]. Organ quality changes can directly reflect the body's obesity. A long-term high-fat diet can lead to a stress reaction in the body, liver lipid accumulation, and other phenomena, leading to hepatomegaly and damaged liver function. ALT and AST are mainly distributed in hepatocytes. When hepatocyte necrosis occurs, ALT and AST are released into the blood circulation, causing serum enzymes to rise; the level is positively correlated with the degree of abnormal liver tissue [24,25]. Blood lipid levels can reflect the whole body's lipid metabolism, and TG, TC, HDL-c, and LDL-c are hallmarks of blood lipids [25]. By exploring the regulatory effect of RBTP on NAFLD and determining the degree of liver enlargement in mice by the liver organ index, it is also possible to 
determine hepatomegaly, liver function, and abnormal blood lipids caused by NAFLD by measuring the markers in the serum. In this study, RBTP effectively lowered abnormal liver enlargement and abnormal serum index, with the alleviation of NAFLD.

Fat accumulation caused by abnormal lipid metabolism induced by NAFLD can also cause chronic tissue inflammation, speeding up the process of fat accumulation and insulin resistance, thus reflecting the abnormal immune system in the body. The accumulation of lipids in the cytoplasm of liver cells (the first hit) triggers a series of cytotoxic events (the second hit), leading to an inflammatory response in the liver. The occurrence and progress of NAFLD are mainly related to insulin and leptin resistance, the production of free radicals, excessive accumulation of visceral fat, and inflammation of adipose tissue and liver tissue [26]. NAFLD causes abnormalities in IL-1beta, IL-4, IL-6, IL-10, TNF-alpha and INF-gamma cytokines. In this study, RBTP also inhibited cytokine abnormalities caused by NAFLD [27-29].

Studies have shown that NAFLD increases the risk of intestinal inflammation, leading to a significant increase in intestinal permeability during intestinal inflammation [30,31]. D-lactic acid is the product of inherent bacteria in gastrointestinal tract. Measuring the level of D-lactic acid in blood can reflect the integrity of intestinal mucosa and the change of intestinal mucosal permeability [32]. LPS may be involved in the inflammatory response of the liver and the accumulation of fat in the liver, which is closely related to the formation of NAFLD [33]. This study also showed that RBTP could reduce the increase of intestinal permeability caused by NAFLD, alleviate intestinal injury, and avoid intestinal dysfunction caused by NAFLD. Additionally, RBTP also could reduce fat accumulation through reducing LPS.

The production of reactive oxygen species (ROS) in the liver exceeds the scavenging capacity of the antioxidant system, resulting in oxygen stress. When oxygen stress increases, ROS reacts with unsaturated fatty acids of membrane phospholipids to form lipid peroxide (LPO), which leads to inflammation, necrosis, and fibrosis [34]. In this study, RBTP has also been demonstrated to alleviate the effects of oxidative stress, protecting the liver and reducing NAFLD by lowering ROS levels in liver tissue.

Peroxisome proliferator-activated receptor (PPAR) is a member of the nuclear receptor transcription factor superfamily that regulates the expression of target genes [35]. PPAR- $\gamma$ is mainly expressed in adipose tissue, which is related to the molecular mechanism of adipocyte overdifferentiation and adipocyte formation. PPAR- $\gamma$ not only regulates the expression of genes related to lipid metabolism, but also is the main regulator of gene expression in adipocytes and signal transduction in insulin cells. C/EBP- $\alpha$ is a transcription factor that plays an important role in adipocyte differentiation and directly regulates adipocyte differentiation. In addition, there is a synergistic effect between C/EBP- $\alpha$ and PPAR $-\gamma$. The activation of PPAR- $\gamma$ can induce the expression of C/EBP- $\alpha$ gene, and C/EBP- $\alpha$ has a positive feedback effect on PPAR- $\gamma[36,37]$.

Carnitine palmitoyl transferase (CPT1) is an important rate-limiting enzyme in the process of fatty acid oxidation (FAO). The level of CPT1 is closely related to the occurrence of hyperlipidemia [38,39]. PPAR- $\alpha$ is an upstream transcription factor in fatty acid oxidation. CPT- 1 is a key downstream target gene. The level of CPT-1 expression in the liver is regulated by its upstream factor PPAR- $\alpha$, and the PPAR- $\alpha /$ CPT- 1 combination is an important pathway in liver lipid metabolism. As a receptor for free fatty acids, PPAR regulates the body's lipid metabolism. PPAR- $\alpha$ accelerates the transport of fatty acids to mitochondria by inducing the expression of specific CPT1 in muscle and liver, and finally promotes the $\beta$ oxidation of fatty acids [40,41]. Lipoprotein lipase (LPL) is a proteolytic enzyme and a key enzyme in lipid metabolism pathway. Its main function is to catalyze the decomposition of triglyceride (TG) in chyle particles (CM) and very low density lipoprotein (VLDL) in plasma into free fatty acids and to promote the transport of proteins, phospholipids, and apolipoproteins, thus promoting the level of high density lipoproteins (HDL) [42,43]. Nearly $50 \%$ of cholesterol in human body is converted into bile acid by the catalysis of CYP7A1. Therefore, the CYP7A1 gene, as the most important regulatory gene in cholesterol synthesis, plays an important role in maintaining cholesterol 
homeostasis and bile acid synthesis [44,45]. In this study, fat accumulation occurred in the liver of mice in the NAFLD model group. RBTP up-regulated the mRNA and protein expression of LPL, PPAR- $\alpha$, CYP7A1, and CPT1 in the liver of NAFLD mice and down-regulated the expression of PPAR- $\gamma$ and $\mathrm{C} / \mathrm{EBP}-\alpha$, thus reducing lipid accumulation in mice induced by high-fat diet and preventing NAFLD.

Intestinal mucosal barrier dysfunction is common in liver diseases. Studies have shown that when NAFLD occurs, intestinal flora alters, intestinal mucosal permeability increases, and the incidence of intestinal endotoxemia becomes high [46]. The anatomical basis of intestinal mucosal epithelial barrier function originates from the tight junctions (TJs) between intestinal epithelial cells. TJs are composed of a variety of tight junction proteins such as ZO-1 and occludin, which play important roles in maintaining epithelial cell polarity and regulating intestinal permeability. Abnormal expression of these tight junction proteins or abnormal distribution of tight junction proteins due to changes in the cytoskeletal structure can lead to destruction of TJs [47]. Clinical studies have shown that the expression of ZO-1 protein in duodenal crypts and intestinal villi in patients with NAFLD is significantly lower than that in normal individuals, and is closely related to increased intestinal permeability and intestinal bacterial overgrowth [41]. Animal experiments have also shown that the expression of ZO-1 and occludin in the small intestine of NAFLD rats is also significantly reduced [48]. These results suggest that the impaired intestinal barrier function in NAFLD may be related to the decreased expression of tight junction proteins.

Lipid deposition in the liver plays a crucial role in the development of NAFLD. Increased intake of dietary fats, especially LCFA, is an important part of free fatty acid intake of human body. Fatty acid transposase CD36, the membrane protein of small intestinal absorptive cells, is located in the brush border membrane of small intestine villus cells and is closely related to LCFA absorption [49]. The expression of TNF- $\alpha$ in small intestinal cells of the NAFLD model is elevated, which promotes the expression of iNOS and increases the synthesis of nitric oxide in small intestinal cells [50]. Increased TNF- $\alpha$ and NO can down-regulate the expression of tight junction proteins in the small intestinal mucosa, resulting in the destruction of tight junction structures, increased the permeability of the small intestinal mucosa, as well as promoting diffusion of the endotoxins produced by the intestinal Gram-negative bacteria [51]. RBTP prevented abnormal protein expressions induced by NAFLD in the small intestine of mice. The effect of RBTP at high concentration was significant and superior to the clinical drug bezafibrate.

Present in-depth research has revealed that intestinal flora disorders play a significant role in the occurrence and development of the nutritional metabolic disease NAFLD [52]. Long-term high-fat and high-sugar diets lead to intestinal flora disorder, which induces the production of harmful bacteria, especially flagellated Gram-negative bacteria, leading to excessive LPS production. LPS enters the blood circulation through damaged intestinal epithelial cells, causing systemic low-grade chronic inflammation in various tissues and organs of the body. When liver dysfunction occurs, the disorder of lipid metabolism leads to fat accumulation, significant fat infiltration in the liver, increased body mass, and impairment of glucose and lipid metabolism [53]. Studies have shown that the abundance of harmful bacteria represented by Firmicutes is reduced and the abundance of beneficial bacteria represented by Bacteroides is increased by improving the disorder of intestinal flora in the development of NAFLD. At the same time, the abundance of bacterial Akkermansia is increased, which significantly inhibits the occurrence and development of NAFLD. Fat accumulation in the liver can be significantly reduced by regulating the proportion of the intestinal microorganisms mentioned above, thereby generally alleviating the pathological symptoms of NAFLD [54]. In this study, we showed that the RBTP gavage could also improve the status of intestinal microorganisms in NAFLD mice and play a role in preventing NAFLD.

Catechin regulates the energy balance of the body, reduces oxidative stress and inflammation, and plays an important role in protecting body tissues in the progression of NAFLD. Catechin can alleviate the degree of hepatic steatosis by reducing adipogenesis and enhancing the antioxidant defense ability of liver in obese rats [55]. Clinical studies have shown that EGCG can reduce ALT, TG, 
and atherosclerotic lipoprotein levels, which lowers the incidence of cardiovascular disease associated with NAFLD [56]. Animal experiments show that gallic acid can reduce fat in obese mice; therefore, it is also reasonable to prevent NAFLD through its lipid-lowering effect [57]. EC, EGC, GCG, and ECG are all active substances with reduced fat-lowering effects, which can prevent cardiovascular diseases and other diseases caused by abnormal lipid metabolism. These active substances can also prevent NAFLD by regulating lipid metabolism [58,59]. Caffeine is not a polyphenolic compound, however, and is difficult to separate from tea polyphenols. When extracting polyphenols from tea leaves, caffeine often coexists with tea polyphenols. Caffeine has the efficacy of increasing the concentration of fatty acids in the blood. Once the concentration of fatty acids increases, the fatty acids are absorbed by the muscles and generate energy, thereby promoting the decomposition of accumulated fat in the body. Therefore, caffeine can also prevent NAFLD by reducing fat [60]. Tea polyphenols are converted into small molecular phenolic acids by the action of intestinal microbes and then are methylated, glucuronated, sulfated, or nucleated into the blood. The role of RBLP may be a combination of many substances. In this study, cell experiments showed that the above compounds monomers could significantly reduce the proliferation of 3T3-L1 preadipocytes. However, at the same concentration, (-)-epicatechin gallate, as the component with the highest RBTP content, was not as effective as mixture RBTP. Among the components contained in RBTP, at the same concentration, only two compounds ((-)-epigallocatechin and (-)-epigallocatechin gallate) were more effective than RBTP. These two components account for only $15.5 \%$ of RBTP content, but they played the most important role in the inhibition of RBTP on adipocytes. Therefore, in further animal experiments, the two components of RBTP should play a central role in NAFLD prevention. Of course, RBLP as a natural substance, in addition to the individual role of compounds, contains a variety of compounds may also produce a certain synergistic effect, enhancing the effect.

Valerolactone is converted into valeric acid by isomerization, and is oxidized or glycinated into phenylacetic, benzoic, hydroxypropionic, and hippuric acids in the liver [61]. The bioavailability of tea polyphenols is improved after they are transformed into small molecular substances by intestinal microorganisms. Under the action of microbes, polyphenols are metabolized into nutrients that can be directly absorbed and affect the lipid metabolism in the intestinal tract of animals [62]. On the other hand, polyphenols can regulate the composition of intestinal microorganisms, especially promote the growth of Bifidobacterium and reduce the proportion of Firmicutes/Bacteroidetes. Drinking tea can increase the proportion of Bifidobacterium in the intestinal tract, promote the development of beneficial intestinal microorganisms, and improving health. Polyphenols regulate the proportion of intestinal microorganisms and the absorption of fatty acids, control lipid metabolism, and play a role in preventing NAFLD [10,62]. Nuclear receptor (NRS), which is a transcription factor activated by ligands, is the main regulator of the metabolism of nutrients in the body. NRS can regulate many transcription factors including PPARs, thus regulating NAFLD [63]. It plays an important role in the prevention of NAFLD. In further research, we will also study the mechanism of RBTP in preventing NAFLD by regulating NRS.

\section{Conclusions}

This study investigated the preventive effect of RBTP on NAFLD in mice. RBTP effectively improved the imbalanced lipid metabolism in the serum and liver tissue, and also reduced the hepatic inflammatory response in NAFLD. RBTP also inhibited the injury of the small intestine, improved the intestinal environment, inhibited harmful bacteria and increased the number of beneficial bacteria, and prevented NAFLD by regulating intestinal function. This study has built the foundation for further research on RBTP. Since only animal studies were carried out in this study, future human clinical trials will be needed to confirm the preventive effect of RBTP on NAFLD.

Author Contributions: B.L. performed the majority of the experiments and wrote the manuscript; J.Z., P.S., R.Y. and X.H. contributed to the data analysis; X.Z. designed and supervised the study and read the final manuscript. 
Funding: This research was funded by the Program for Innovation Team Building at Institutions of Higher Education in Chongqing (CXTDX201601040) and the Scientific Research Foundation for Returned Overseas Chinese Scholars, and the State Education Ministry [Jiaowaisiliu (2014)1685], China.

Conflicts of Interest: The authors declare no conflict of interest.

\section{References}

1. Italian Association for the Study of the Liver. AISF position paper on nonalcoholic fatty liver disease (NAFLD): Updates and future directions. Dig. Liver Dis. 2017, 49, 471-483. [CrossRef] [PubMed]

2. Stefan, N.; Schick, F.; Häring, H.U. Ectopic fat in insulin resistance, dyslipidemia, and cardiometabolic disease. N. Engl. J. Med. 2014, 371, 2236-2237. [PubMed]

3. Donnelly, K.L.; Smith, C.I.; Schwarzenberg, S.J.; Jessurun, J.; Boldt, M.D.; Parks, E.J. Sources of fatty acids stored in liver and secreted via lipoproteins in patients with nonalcoholic fatty liver disease. J. Clin. Investig. 2005, 115, 1343-1351. [CrossRef] [PubMed]

4. $\mathrm{Xu}, \mathrm{L} . ;$ Deng, D.H.; Cai, C.B. Predicting the age and type of tuocha tea by fourier transform infrared spectroscopy and chemometric data analysis. J. Agric. Food Chem. 2011, 59, 10461-10469. [CrossRef] [PubMed]

5. Song, L.B.; Huang, J.A.; Liu, Z.H.; Huang, H.; Wang, K.B. Study on activity of Dark Tea extracts on PPARs model. J. Tea Sci. 2008, 28, 319-325.

6. Zhao, Z.J.; Liu, J.Q. The functional constituents of Xiaguan Xiaotuocha and its hypolipidemic effect. Hubei Agric. Sci. 2013, 52, 1334-1337.

7. Liu, H.B.; Wang, M.Y.; Li, Z.C.; Zhou, W.X.; Li, Z.B.; Huang, J.Z.; Shan, L. Observation on the therapeutic effect of Yunnan Tuocha on hyperlipidemia (comparing with antamine). Acta Acad. Med. Kunming 1981, Z1, $51-54$.

8. Xu, C.; Wan, X.; Xu, L.; Weng, H.; Yan, M.; Miao, M.; Sun, Y.; Xu, G.; Dooley, S.; Li, Y.; et al. Xanthine oxidase in non-alcoholic fatty liver disease and hyperuricemia: One stone hits two birds. J. Hepatol. 2015, 62, 1412-1419. [CrossRef]

9. Nobili, V.; Svegliati-Baroni, G.; Alisi, A.; Miele, L.; Valenti, L.; Vajro, P. A 360-degree overview of paediatric NAFLD: Recent insights. J. Hepatol. 2013, 58, 1218-1229. [CrossRef]

10. Zhu, S.Y.; Tong, Y.L.; Zhao, Y.; Lv, H.P.; Lin, Z.; Shen, G.L.; Sun, T.; Song, Z.Y. Effect of Pu-erh tea on long chain fatty acid metabolism and expression of tight junction proteins in the rat model of non-alcoholic fatty liver disease. J. Tea Sci. 2016, 36, 237-244.

11. De Minicis, S.; Rychlicki, C.; Agostinelli, L.; Saccomanno, S.; Candelaresi, C.; Trozzi, L.; Mingarelli, E.; Facinelli, B.; Magi, G.; Palmieri, C.; et al. Dysbiosis contributes to fibrogenesis in the course of chronic liver injury in mice. Hepatology 2014, 59, 1738-1749. [CrossRef] [PubMed]

12. Aron-Wisnewsky, J.; Gaborit, B.; Dutour, A.; Clement, K. Gut microbiota and non-alcoholic fatty liver disease: New insights. Clin. Microbiol. Infect. 2013, 19, 338-348. [CrossRef] [PubMed]

13. Tan, Y.; Kim, J.; Cheng, J.; Ong, M.; Lao, W.G.; Jin, X.L.; Lin, Y.G.; Xiao, L.; Zhu, X.Q.; Qu, X.Q. Green tea polyphenols ameliorate non-alcoholic fatty liver disease through upregulating AMPK activation in high fat fed Zucker fatty rats. World J. Gastroenterol. 2017, 23, 3805-3814. [CrossRef] [PubMed]

14. Hui, R.H.; Hou, D.Y.; Guan, C.X.; Liu, X.Y. Identification of catechin in Tuo Tea. J. Chin. Mass Spectrom. Soc. 2004, 25, 42-44.

15. Qian, Y.; Zhang, J.; Fu, X.; Yi, R.; Sun, P.; Zou, M.; Long, X.; Zhao, X. Preventive effect of raw Liubao Tea polyphenols on mouse gastric injuries induced by HCl/ethanol via anti-oxidative stress. Molecules 2018, 23, 2848. [CrossRef] [PubMed]

16. Cho, J.; Lee, I.; Kim, D.; Koh, Y.; Kong, J.; Lee, S.; Kang, H. Effect of aerobic exercise training on non-alcoholic fatty liver disease induced by a high fat diet in C57BL/6 mice. J. Exerc. Nutr. Biochem. 2014, 18, 339-346. [CrossRef] [PubMed]

17. Qian, Y.; Zhang, J.; Zhou, X.; Yi, R.; Mu, J.; Long, X.; Pan, Y.; Zhao, X.; Liu, W. Lactobacillus plantarum CQPC11 isolated from sichuan pickled cabbages antagonizes d-galactose-induced oxidation and aging in mice. Molecules 2018, 23, 3026. [CrossRef]

18. Pan, Y.; Long, X.; Yi, R.; Zhao, X. Polyphenols in Liubao tea can prevent $\mathrm{CCl}_{4}$-induced hepatic damage in mice through its antioxidant capacities. Nutrients 2018, 10, 1280. [CrossRef] 
19. Fazel, Y.; Koenig, A.B.; Sayiner, M.; Goodman, Z.D.; Younossi, Z.M. Epidemiology and natural history of non-alcoholic fattyliver disease. Metabolism 2016, 65, 1017-1025. [CrossRef]

20. Day, C.P.; James, O.F. Steatohepatitis: A tale of two “hits"? Gastroenterology 1998, 114, 842-845. [CrossRef]

21. Carmody, R.N.; Gerber, G.K.; Luevano, J.M.; Gatti, D.M.; Somes, L.; Svenson, K.L.; Turnbaugh, P.J. Diet dominates host genotype in shaping the murine gut microbiota. Cell Host Microbe 2015, 17, 72-84. [CrossRef] [PubMed]

22. Liu, J.P.; Zou, W.L.; Chen, S.J.; Wei, H.Y.; Yin, Y.N.; Zou, Y.Y.; Lu, F.G. Effects of different diets on intestinal microbiota and nonalcoholic fatty liver disease development. World J. Gastroenterol. 2016, 22, 7353-7364. [CrossRef] [PubMed]

23. Lee, S.; Han, D.; Kang, H.; Jeong, S.J.; Jo, J.E.; Shin, J.; Kim, D.K.; Park, H.W. Intravenous sustained-release nifedipine ameliorates nonalcoholic fatty liver disease by restoring autophagic clearance. Biomaterials 2019, 197, 1-11. [CrossRef] [PubMed]

24. Al Zarzour, R.H.; Ahmad, M.; Asmawi, M.Z.; Kaur, G.; Saeed, M.A.A.; Al-Mansoub, M.A.; Saghir, S.A.M.; Usman, N.S.; Al-Dulaimi, D.W.; Yam, M.F. Phyllanthus Niruri standardized extract alleviates the progression of non-alcoholic fatty liver disease and decreases atherosclerotic risk in Sprague-Dawley Rats. Nutrients 2017, 9, 766. [CrossRef] [PubMed]

25. Panelli, M.F.; Pierine, D.T.; De Souza, S.L.B.; Ferron, A.J.T.; Garcia, J.L.; Santos, K.C.; Belin, M.A.F.; Lima, G.P.P.; Borguini, M.G.; Minatel, I.O.; et al. Bark of Passiflora edulis treatment stimulates antioxidant capacity, and reduces dyslipidemia and body fat in $d b / d b$ mice. Antioxidants 2018, 7, 120. [CrossRef] [PubMed]

26. Xu, M.X.; Sun, Y.; Dai, X.L.; Zhan, J.X.; Long, T.T.; Xiong, M.X.; Li, H.H.; Kuang, Q.; Tang, T.T.; Qin, Y.T.; et al. Fisetin attenuates high fat diet-triggered hepatic lipid accumulation: A mechanism involving liver inflammation overload associated TACE/TNF- $\alpha$ pathway. J. Funct. Foods 2019, 53, 7-21.

27. Yu, Y.; Liu, Y.; An, W.; Song, J.; Zhang, Y.; Zhao, X. STING-mediated inflammation in Kupffer cells contributes to progression of nonalcoholic steatohepatitis. J. Clin. Investig. 2019, 129, 546-555. [CrossRef] [PubMed]

28. Barroso, M.V.; Graça-Reis, A.; Cattani-Cavalieri, I.; Gitirana, L.B.; Valenca, S.S.; Lanzetti, M. Mate tea reduces high fat diet-induced liver and metabolic disorders in mice. Biomed. Pharmacother. 2019, 109, 1547-1555. [CrossRef]

29. de Souza Teixeira, A.A.; Souza, C.O.; Biondo, L.A.; Sanches Silveira, L.; Lima, E.A.; Batatinha, H.A.; Araujo, A.P.; Alves, M.J.; Hirabara, S.M.; Curi, R.; et al. Short-term treatment with metformin reduces hepatic lipid accumulation but induces liver inflammation in obese mice. Inflammopharmacology 2018, 26, 1103-1115. [CrossRef]

30. Yao, Y.M.; Yu, Y.; Wu, Y.; Lu, L.R.; Sheng, Z.Y. Plasma D (-)-lactate as a new marker for diagnosis of acute intestinal injury following ischemia-reperfusion. World J. Gastroenterol. 1997, 3, 225-227. [CrossRef]

31. Sun, Z.; Wang, X.; Wallen, R.; Deng, X.; Du, X.; Hallberg, E.; Andersson, R. The influence of apoptosis on intestinal barrier integrity in rats. Scand. J. Gastroenterol. 1998, 33, 415-422. [PubMed]

32. Feng, S.; Liu, W.; Zuo, S.; Xie, T.; Deng, H.; Zhang, Q.; Zhong, B. Impaired function of the intestinal barrier in a novel sub-health rat model. Mol. Med. Rep. 2016, 13, 3459-3465. [CrossRef] [PubMed]

33. Brun, P.; Castagliuolo, I.; Di Leo, V.; Buda, A.; Pinzani, M.; Palù, G.; Martines, D. Increased intestinal permeability in obese mice: New evidence in the pathogenesis of nonalcoholic steatohepatitis. Am. J. Physiol. Gastrointest. Liver Physiol. 2007, 292, 518-525. [CrossRef] [PubMed]

34. Yang, F.; Shang, L.; Wang, S.; Liu, Y.; Ren, H.; Zhu, W.; Shi, W. TNF $\alpha$-mediated necroptosis aggravates ischemia-reperfusion injury in the fatty liver by regulating the inflammatory response. Oxid. Med. Cell Longev. 2019, 2019, 2301903. [CrossRef] [PubMed]

35. Khajebishak, Y.; Payahoo, L.; Alivand, M.; Alipour, B. Punicic acid: A potential compound of pomegranate seed oil in Type 2 diabetes mellitus management. J. Cell. Physiol. 2019, 234, 2112-2120. [CrossRef] [PubMed]

36. Kang, M.J.; Kim, K.K.; Son, B.Y.; Nam, S.W.; Shin, P.G.; Kim, G.D. The anti-adipogenic activity of a new cultivar, Pleurotus eryngii var. ferulae 'Beesan No. $2^{\prime}$, through down-regulation of PPAR $\gamma$ and C/EBP $\alpha$ in 3T3-L1 cells. J. Microbiol. Biotechnol. 2016, 26, 1836-1844. [CrossRef]

37. Kim, H.J.; You, M.K.; Lee, Y.H.; Kim, H.J.; Adhikari, D.; Kim, H.A. Red pepper seed water extract inhibits preadipocyte differentiation and induces mature adipocyte apoptosis in 3T3-L1 cells. Nutr. Res. Pract. 2018, 12, 494-502. [CrossRef]

38. Lundsgaard, A.M.; Fritzen, A.M.; Kiens, B. Molecular regulation of fatty acid oxidation in skeletal muscle during aerobic exercise. Trends Endocrinol. Metab. 2018, 29, 18-30. [CrossRef] 
39. Freitag, L.H. Genetic variation of fatty acid oxidation and obesity, a literature review. Int. J. Biomed. Sci. 2016, $12,1-8$

40. Lee, S. Hypolipidemic Effect of hexane fraction from Rhizopus oryzae KSD-815. J. Kor. Soc. Appl. Biol. Chem. 2010, 53, 761-765. [CrossRef]

41. Colom, C.; Viladés, D.; Pérez-Cuellar, M.; Leta, R.; Rivas-Urbina, A.; Carreras, G.; Ordóñez-Llanos, J.; Pérez, A.; Sánchez-Quesada, J.L. Associations between epicardial adipose tissue, subclinical atherosclerosis and high-density lipoprotein composition in type 1 diabetes. Cardiovasc. Diabetol. 2018, 17, 156. [CrossRef] [PubMed]

42. Su, X.; Kong, Y.; Peng, D. New insights into apolipoprotein A5 in controlling lipoprotein metabolism in obesity and the metabolic syndrome patients. Lipids Health Dis. 2018, 17, 174. [CrossRef] [PubMed]

43. Cruciani-Guglielmacci, C.; Magnan, C. Brain lipoprotein lipase as a regulator of energy balance. Biochimie 2017, 143, 51-55. [CrossRef] [PubMed]

44. Yang, D.; Hu, C.; Deng, X.; Bai, Y.; Cao, H.; Guo, J.; Su, Z. Therapeutic effect of chitooligosaccharide tablets on lipids in high-fat diets induced hyperlipidemic rats. Molecules 2019, 24, 514. [CrossRef] [PubMed]

45. Tanaka, Y.; Ikeda, T.; Yamamoto, K.; Masuda, S.; Ogawa, H.; Kamisako, T. Gender-divergent expression of lipid and bile acid metabolism-related genes in adult mice offspring of dams fed a high-fat diet. J. Biosci. 2018, 43, 329-337. [CrossRef] [PubMed]

46. Miele, L.; Valenza, V.; La Torre, G.; Montalto, M.; Cammarota, G.; Ricci, R.; Mascianà, R.; Forgione, A.; Gabrieli, M.L.; Perotti, G.; et al. Increased intestinal permeability and tight junction alterations in nonalcoholic fatty liver disease. Hepatology 2009, 49, 1877-1887. [CrossRef] [PubMed]

47. Wigg, A.J.; Roberts-Thomson, I.C.; Dymock, R.B.; McCarthy, P.J.; Grose, R.H.; Cummins, A.G. The role of small intestinal bacterial overgrowth, intestinal permeability, endotoxaemia, and tumour necrosis factor alpha in the pathogenesis of non-alcoholic steatohepatitis. Gut 2001, 48, 206-211. [CrossRef] [PubMed]

48. Endo, H.; Niioka, M.; Kobayashi, N.; Tanaka, M.; Watanabe, T. Butyrate-producing probiotics reduce nonalcoholic fatty liver disease progression in rats: New insight into the probiotics for the gut-liver axis. PLoS ONE 2013, 8, e63388. [CrossRef] [PubMed]

49. Ogawa, Y.; Imajo, K.; Yoneda, M.; Nakajima, A. Pathophysiology of NAsh/NAFLD associated with high levels of serum triglycerides. Nihon. Rinsho. 2013, 71, 1623-1629.

50. Han, X.; Fink, M.P.; Yang, R.; Delude, R.L. Increased iNOS activity is essential for intestinal epithelial tight junction dysfunction in endotoxemic mice. Shock 2004, 21, 261-270. [CrossRef]

51. Reid, A.E. Nonalcoholic steatohepatitis. Gastroenterology 2001, 121, 710-723. [CrossRef] [PubMed]

52. Minemura, M.; Shimizu, Y. Gut microbiota and liver diseases. World J. Gastroenterol. 2015, 21, 1691-1702. [CrossRef] [PubMed]

53. Hooper, L.V.; Wong, M.H.; Thelin, A.; Hansson, L.; Falk, P.G.; Gordon, J.I. Molecular analysis of commensal host-microbial relationships in the intestine. Science 2001, 291, 881-884. [CrossRef] [PubMed]

54. Lu, X.J.; Liu, J.X.; Cao, Y.G.; Fu, Y.H.; Zhang, Z.C.; Li, Y.X.; Wang, W.Q.; Li, Y.X.; Shen, P.; Zhang, N.S. Pu-er tea extract modulating lipid metabolism and gut microbiota in nonalcoholic fatty liver disease mice. Chin. J. Vet. Sci. 2018, 38, 751-758.

55. Bruno, R.S.; Dugan, C.E.; Smyth, J.A.; DiNatale, D.A.; Koo, S.I. Green tea extract protects leptin-deficient, spontaneously obese mice from hepatic steatosis and injury. J. Nutr. 2008, 138, 323-331. [CrossRef] [PubMed]

56. Kuriyama, S.; Shimazu, T.; Ohmori, K.; Kikuchi, N.; Nakaya, N.; Nishino, Y.; Tsubono, Y.; Tsuji, I. Green tea consumption and mortality due to cardiovascular disease, cancer, and all causes in Japan: The Ohsaki study. JAMA 2006, 296, 1255-1265. [CrossRef]

57. Zhang, X.; Chen, C.Y.; Dong, J.L.; Cai, J.Y.; Zhao, S.L. Lipid-lowering effects of gallic acid on glutamate-induced obese mice. Chin. Tradit. Patent Med. 2017, 39, 1115-1119.

58. Han, Y.S.; Chu, J.; Ge, Z.M. Protective effect of (-)-epigallocatechin gallate on cardiovascular health. Chin. J. Pathophysiol. 2012, 28, 1521-1525.

59. Xie, J.; Wei, J.; Zhou, L.W.; He, J.L.; Wang, Q.L.; Du, L.L. Contents determination of catechins active components in lipid-lowering slimming health products by quantitative analysis of multi-components via single marker. China Pharm. 2017, 28, 2529-2532.

60. Harpaz, E.; Tamir, S.; Weinstein, A.; Weinstein, Y. The effect of caffeine on energy balance. J. Basic Clin. Physiol. Pharmacol. 2017, 28,1-10. [CrossRef] 
61. Williamson, G.; Clifford, M.N. Role of the small intestine, colon and microbiota in determining the metabolic fate of polyphenols. Biochem. Pharmacol. 2017, 139, 24-39. [CrossRef] [PubMed]

62. Liu, D.M.; Huang, J.A.; Liu, Z.H. The regulation effect of interaction between gut microbiota and tea and tea polyphenols in obesity and comorbidity. Nat. Prod. Res. Dev. 2018, 30, 1640-1648.

63. Ballestri, S.; Nascimbeni, F.; Romagnoli, D.; Baldelli, E.; Lonardo, A. The role of nuclear receptors in the pathophysiology, natural course, and drug treatment of NAFLD in humans. Adv. Ther. 2016, 33, 291-319. [CrossRef] [PubMed]

(C) 2019 by the authors. Licensee MDPI, Basel, Switzerland. This article is an open access article distributed under the terms and conditions of the Creative Commons Attribution (CC BY) license (http://creativecommons.org/licenses/by/4.0/). 